\title{
Potential mechanisms of cerebrovascular diseases in COVID-19 patients
}

\author{
Manxue Lou ${ }^{1} \cdot$ Dezhi Yuan ${ }^{2,3} \cdot$ Shengtao Liao ${ }^{4} \cdot$ Linyan Tong $^{1} \cdot$ Jinfang $\mathrm{Li}^{1}$
}

Received: 23 June 2020 / Revised: 31 December 2020 / Accepted: 14 January 2021 / Published online: 3 February 2021

(c) Journal of NeuroVirology, Inc. 2021

\begin{abstract}
Since the outbreak of coronavirus disease 2019 (COVID-19) in 2019, it is gaining worldwide attention at the moment. Apart from respiratory manifestations, neurological dysfunction in COVID-19 patients, especially the occurrence of cerebrovascular diseases (CVD), has been intensively investigated. In this review, the effects of COVID-19 infection on CVD were summarized as follows: (I) angiotensin-converting enzyme 2 (ACE2) may be involved in the attack on vascular endothelial cells by severe acute respiratory syndrome coronavirus-2 (SARS-CoV-2), leading to endothelial damage and increased subintimal inflammation, which are followed by hemorrhage or thrombosis; (II) SARS-CoV-2 could alter the expression/activity of ACE2, consequently resulting in the disruption of renin-angiotensin system which is associated with the occurrence and progression of atherosclerosis; (III) upregulation of neutrophil extracellular traps has been detected in COVID-19 patients, which is closely associated with immunothrombosis; (IV) the inflammatory cascade induced by SARSCoV-2 often leads to hypercoagulability and promotes the formation and progress of atherosclerosis; (V) antiphospholipid antibodies are also detected in plasma of some severe cases, which aggravate the thrombosis through the formation of immune complexes; (VI) hyperglycemia in COVID-19 patients may trigger CVD by increasing oxidative stress and blood viscosity; (VII) the COVID-19 outbreak is a global emergency and causes psychological stress, which could be a potential risk factor of CVD as coagulation, and fibrinolysis may be affected. In this review, we aimed to further our understanding of CVD-associated COVID-19 infection, which could improve the therapeutic outcomes of patients. Personalized treatments should be offered to COVID-19 patients at greater risk for stroke in future clinical practice.
\end{abstract}

Keywords COVID-19 $\cdot$ SARS-CoV-2 $\cdot$ Cerebrovascular disease $\cdot$ Stroke

\begin{tabular}{ll}
\multicolumn{2}{l}{ Abbreviations } \\
COVID-19 & Coronavirus disease 2019 \\
CVD & Cerebrovascular diseases \\
AIS & Acute ischemic stroke \\
CKD & Chronic kidney disease \\
N/A & Not applicable
\end{tabular}

Jinfang Li

lijinfang@hospital.cqmu.edu.cn

1 Department of Neurology, Second Affiliated Hospital of Chongqing Medical University, Chongqing 400010, China

2 Department of Neurology, First Affiliated Hospital of Army Medical University (Chongqing Southwest Hospital), Chongqing 400038, China

3 Department of Neurology, People's Hospital of Shapingba District, Chongqing 400038, China

4 Department of Gastroenterology, Second Affiliated Hospital of Chongqing Medical University, Chongqing 400010, China

$\begin{array}{ll}\text { MCA } & \text { Middle cerebral artery } \\ \text { ACA } & \text { Anterior cerebral artery } \\ \text { WBC } & \text { White blood cell } \\ \text { PT } & \text { Prothrombin time } \\ \text { D-D } & \text { D-dimer } \\ \text { aCL } & \text { Anticardiolipin } \\ \text { AF } & \text { Atrial fibrillation } \\ \text { CRP } & \text { C-reactive protein } \\ \text { a } \beta 2 \text { GP1 } & \text { Anti- } \beta 2 \text {-glycoprotein-1 } \\ \text { ICU } & \text { Intense care unit } \\ \text { APTT } & \text { Activated partial thromboplastin time } \\ \text { PLT } & \text { Platelet } \\ \text { SAH } & \text { Subarachnoid hemorrhage } \\ \text { PICA } & \text { Posterior-inferior cerebellar artery }\end{array}$




\section{Introduction}

At the end of 2019, coronavirus disease 2019 (COVID-19) was discovered in Wuhan, China, followed by the global outbreak (Chan et al. 2020; Wang C et al. 2020); . COVID-19 infection is caused by a novel coronavirus, which was named as severe acute respiratory syndrome (SARS) coronavirus-2 (SARS-CoV-2) by the International Committee on Taxonomy of Viruses (Chan et al. 2020). On 11 March 2020, the World Health Organization (WHO) officially announced the COVID19 outbreak a global pandemic. Until 21 December 2020, $75,479,471$ cases have been confirmed worldwide including 1,686,267 deaths (https://covid19.who.int).

The COVID-19 infection is a type of viral pneumonia. However, apart from respiratory symptoms, some patients also exhibit neurological dysfunction (Huang et al. 2020). Furthermore, a previous study by Mao et al. has revealed the neurological manifestations in COVID-19 patients for the first time, which attracts physicians' particular attention to the neurological deficits caused by SARS-CoV-2 (Mao et al. 2020). Additionally, the patients with cerebrovascular diseases (CVD) have worse therapeutic outcomes and are more easily overlooked than other patients (Mao et al. 2020). During the pandemic of COVID-19, it is thus essential to further our understanding of the association between COVID-19 infection and neurological dysfunction, especially the effects on cerebrovascular system. Therefore, comprehensive treatments could be developed, and the therapeutic outcomes may be improved. In this review, the existing knowledge in SARS-CoV-2 was summarized, and the epidemiological characteristics and neurological manifestations in COVID-19 patients were analyzed. Moreover, the association between COVID-19 infection and the occurrence of CVD was elucidated. Our aim was to review the potential pathophysiological mechanisms and provide guidance for follow-up research and future clinical practice.

\section{Background of SARS-CoV-2}

Coronaviruses belong to the family of Coronaviridae, which is divided into four genera, $\alpha, \beta, \gamma$, and $\delta$ (Fung and Liu 2019). Seven coronavirus strains are able to infect humans and cause respiratory diseases, including severe acute respiratory syndrome coronavirus-1 (SARS-CoV-1), Middle East respiratory syndrome coronavirus (MERS$\mathrm{CoV}$ ), and the newly discovered SARS-CoV-2 (Fung and Liu 2019; Zhou et al. 2020). The abovementioned strains are pathogenic $\beta$-coronaviruses which could cause regional or even global outbreaks (Fung and Liu 2019; Lu et al. 2020; Oboho et al. 2015; Peiris et al. 2003; Wang C et al. 2020). Among them, Lu et al. and Chan et al. have reported that SARS-CoV-2 shares a highly similar gene sequence ( 79\%) with SARS-CoV-1; thus, they are highly homologous.

\section{Neurological manifestations in COVID-19 patients}

Fever, dry cough, and fatigue are the most common symptoms at the onset of SARS-CoV-2 infection (Guan et al. 2020a, b; Wang et al. 2020). Although neurological symptoms are not often observed, small proportion of COVID-19 patients still exhibits neurological dysfunction. A previous study of the Union Hospital of Tongji Medical College, Huazhong University of Science and Technology (Wuhan, China), has revealed the characteristic neurologic manifestations in COVID-19 patients for the first time (Mao et al. 2020). A total of 214 cases were enrolled in this study, containing 78 patients (36.4\%) with neurological symptoms and six cases with acute cerebrovascular disease (ACVD). Furthermore, two patients with ACVD did not exhibit the common symptoms such as fever and cough; however, the first symptom was sudden hemiplegia (Mao et al. 2020). These findings suggest that COVID-19 patients whose first symptom was ACVD alone could be missed or misdiagnosed. In this review, more COVID-19 cases with the occurrence of CVD were summarized (Table 1)(Al Saiegh et al. 2020; Avula et al. 2020; Beyrouti et al. 2020; Goldberg et al. 2020; Oxley et al. 2020; Tunç et al. 2020; Zhang Y et al. 2020). More importantly, according to the early published data, the fatality rate of COVID-19 patients with CVD is $~ 10.5 \%$ in China, which indicates that the occurrence of CVD in COVID19 patients could lead to unfavorable outcomes (Novel Coronavirus Pneumonia Emergency Response Epidemiology Team 2020). Furthermore, patients with pre-existing chronic conditions, such as hypertension and diabetes, exhibit higher infection rate and poorer prognosis (Guan et al. 2020a, b). Aging, hypertension, and diabetes are the risk factors for the occurrence of cerebrovascular events (Boehme et al. 2017). As the outbreaks generally occur in winter, when the incidence of CVD is higher, more attention should be paid to the monitoring of elderly patients with severe COVID-19, especially those with cerebrovascular diseases or who have already developed CVD.

\section{Potential mechanisms of COVID-19-induced cerebrovascular diseases}

As previously reported, the risk of death in SARS patients was also increased by the occurrence of CVD (Wang et al. 2012). A previous study on five SARS cases with newly diagnosed large artery stroke suggested that 


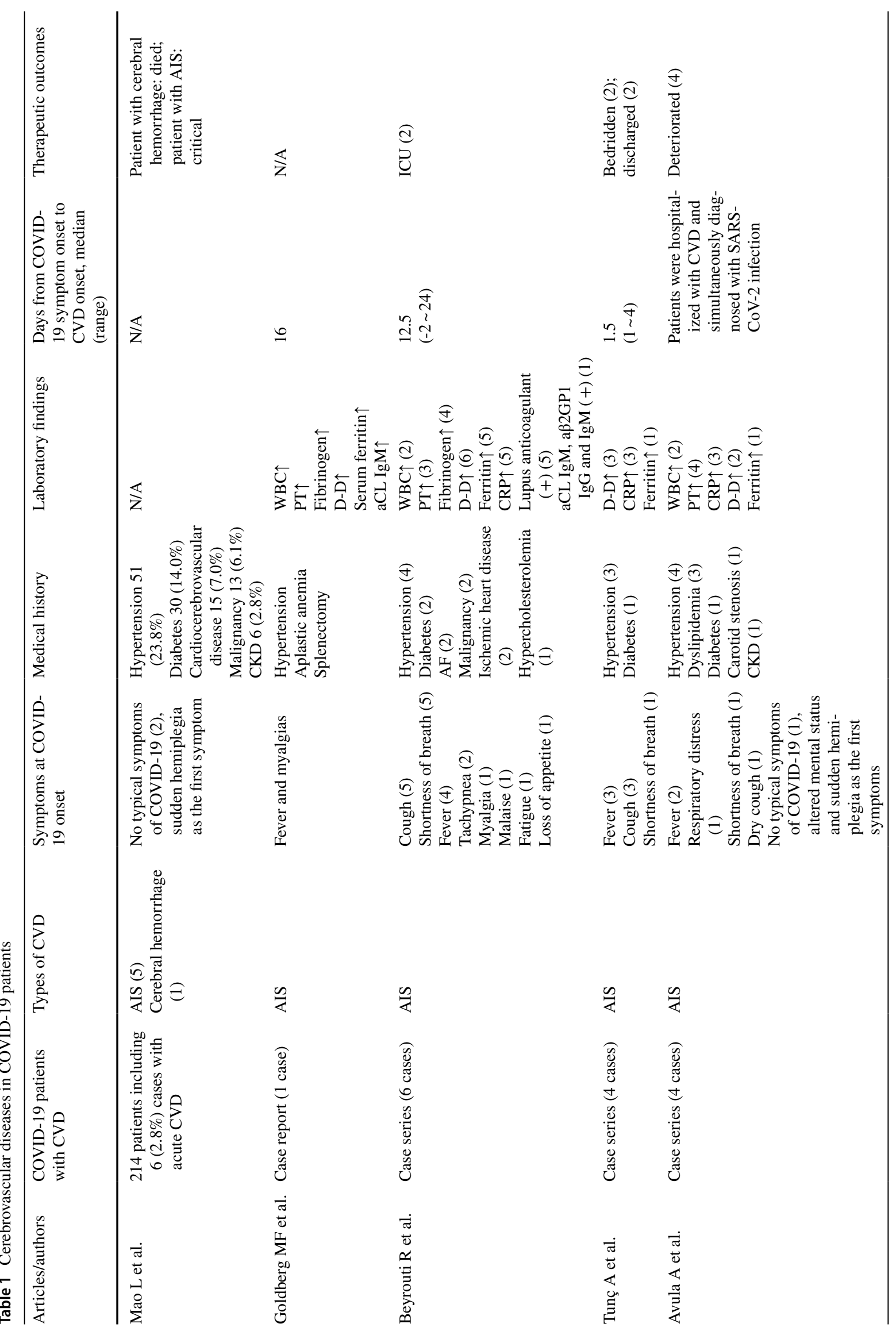




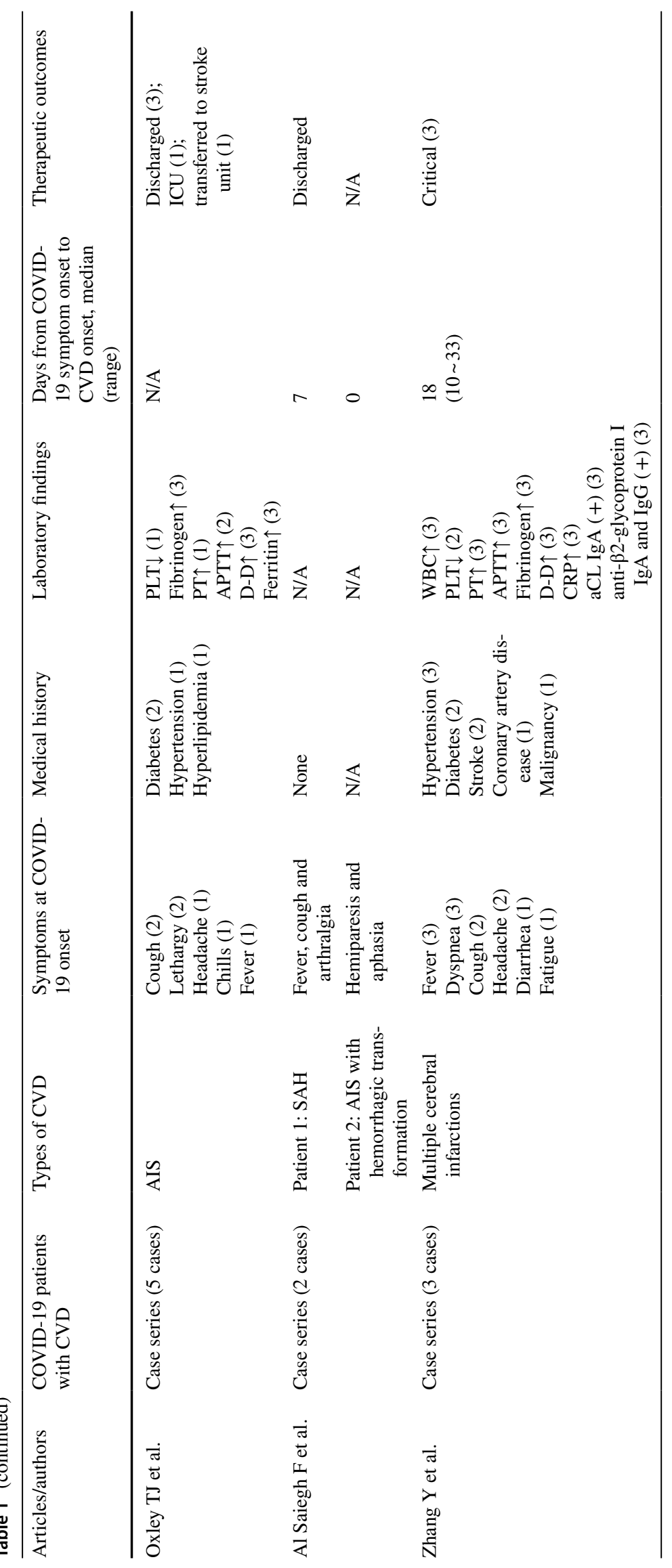


SARS-CoV-1 could trigger CVD and lead to worse outcomes (Umapathi et al. 2004). Furthermore, another study on 1291 SARS patients with confirmed CVD indicated that CVD is one of the most important risk factors in patients with SARS (Hu et al. 2004). Due to the current understanding of SARS-CoV-2-related CVD and the similarity of COVID-19 and SARS in terms of epidemiology, clinical manifestations, radiologic findings, and laboratory tests (Chan et al. 2020; Song et al. 2019), it is reasonable to use SARS-CoV-1 infection as a reference. In addition, Janardhan et al. has recently suggested that COVID-19 infection may be essentially a blood clotting disorder masquerading as a respiratory disease, as it involves the accumulation of angiotensin II (Ang II), oxidative stress, endothelial dysfunction, formation of antiphospholipid (APL) antibody complexes, platelet aggregation, coagulation cascade, and formation of cross-linked fibrin blood clots (Janardhan et al. 2020). This study also provides guidance to further explore the novel association between COVID-19 and CVD. After comprehensive analyses of the existing data, we hypothesized that COVID-19 may affect CVD through the following mechanisms (Fig. 1).

\section{Attack against vascular endothelial cells by SARS-CoV-2}

It is well established that SARS-CoV-2 and SARS-CoV-1 both enter the host cells through the recognition by angiotensin-converting enzyme 2 (ACE2), and the affinity of SARS-CoV-2 spike protein to ACE2 is much higher compared with SARS-CoV-1 (Li et al. 2003; Lu et al. 2020; Wan et al. 2020; Wrapp et al. 2020). The peptidase ACE2 is located on the surface of alveolar epithelial cells, small intestinal epithelial cells, vascular endothelial cells, arterial smooth muscle cells, immune cells, and neurons (Baig et al. 2020; Madjid et al. 2020). Therefore, SARSCoV-2 may directly attack vascular endothelial cells via the ACE2 receptor, resulting in endothelial cell dysfunction and endothelial barrier damage (Janardhan et al. 2020). Furthermore, scholars have revealed the presence of SARSCoV-2 in brain capillary endothelial cells in a COVID-19 patient (Paniz-Mondolfi et al. 2020).

Moreover, damage to the endothelium of cerebral capillaries may lead to endothelial ruptures accompanied by hemorrhage within cerebral tissues (Baig et al. 2020). Endothelial cells serve as a natural barrier by isolating

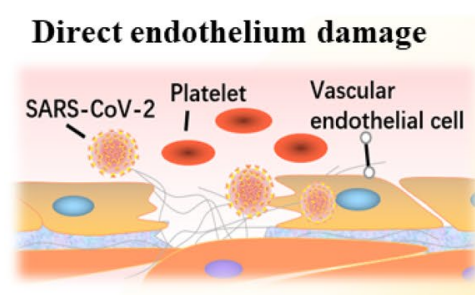

Downregulation of ACE2
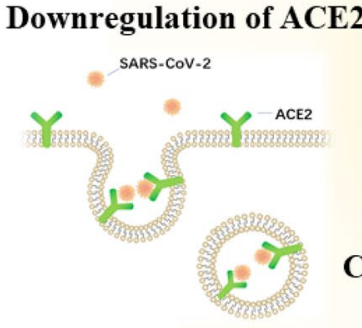

Formation of anti- $\beta 2$ GP1- $\beta 2$ GP1 complexes
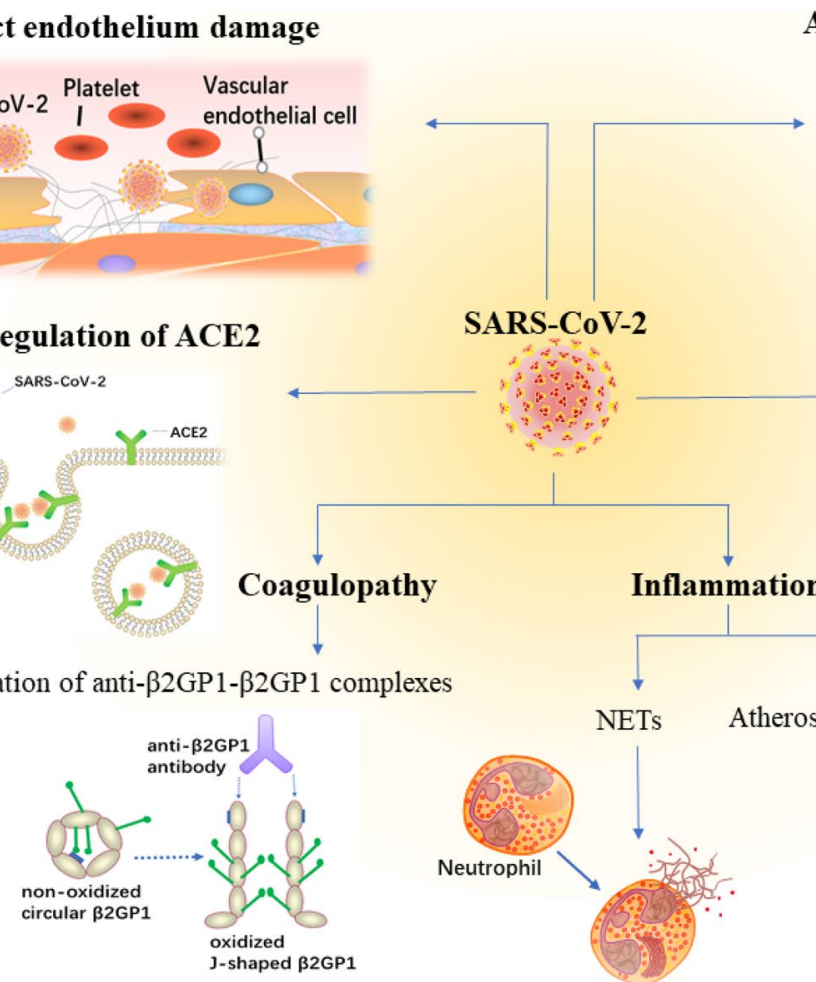

SARS-CoV-2

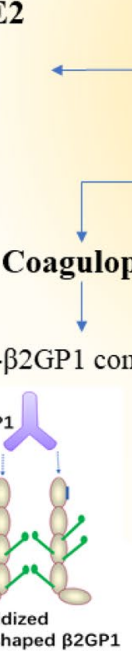

a
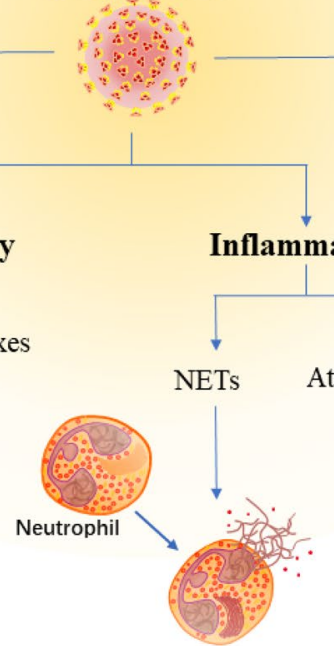

\section{Acute stress response}

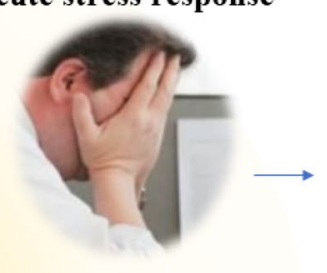

Hyperglycemia state
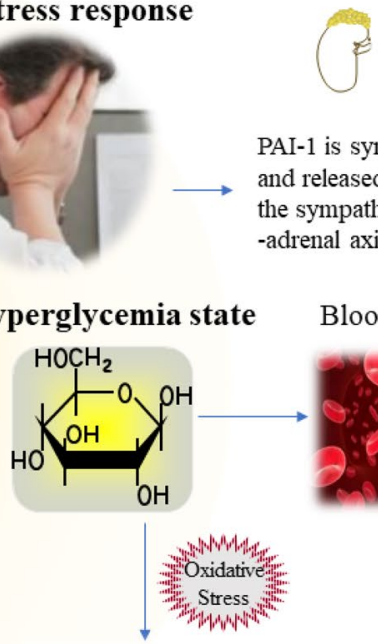

PAI-1 is synthesized and released from

the sympathetic -adrenal axis

\section{Blood viscosity $\uparrow$}

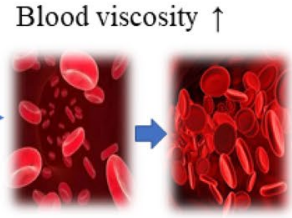

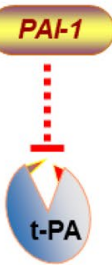

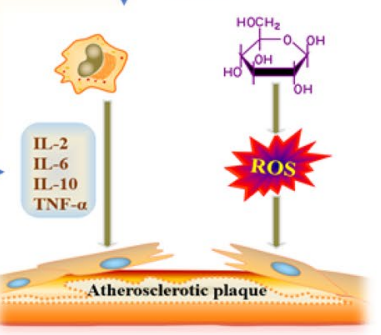

Fig. 1 Potential mechanisms of cerebrovascular diseases in COVID19 patients. The potential mechanisms mainly include ACE2-mediated endothelium damage, downregulation of ACE2, acute infection-related inflammation and coagulopathy, formation of NETs and APL antibodies, hyperglycemia, and acute stress reaction. These are the risk factors of cardiocerebrovascular events in COVID-19 patients 
platelets and coagulation factors from subintimal collagen, and they can produce heparin and vasodilating factors to regulate coagulation, fibrinolysis, and platelet activation (Prasad et al. 2016; van Hinsbergh 2012). If the endothelium is damaged, exposed subintimal collagen could induce platelet aggregation and adhesion, consequently leading to thrombosis and promoting the occurrence of ischemic events (Poredos and Jezovnik 2018). In addition, upon the damage of endothelium, numerous adhesion molecules are produced, and chemokines are released to recruit inflammatory cells. Furthermore, the disruption of cell permeability and intercellular barrier structure accelerates the penetration of inflammatory cells through the endodermis to the vascular wall and surrounding tissues, resulting in inflammatory infiltration (Chatzizisis et al. 2007; Poredos and Jezovnik 2018; van Hinsbergh 2012). In addition, tissue interstitial edema was observed in various infected organs of some severe COVID-19 patients, as well as infiltration of mononuclear cells/lymphocytes, vascular endothelial inflammation/exfoliation, and intravascular transparent microthrombosis (Xu et al. 2020; Yao et al. 2020; Zhang et al. 2020). Moreover, similar pathologic features were detected in SARS patients with confirmed systemic vasculitis (Ding et al. 2003). Though the mechanisms of vasculitis are complex, it is suggested that the vessels at lesion site may form aneurysms due to reduced elasticity, which increases the risk of rupture and bleeding (Liberman et al. 2014). Moreover, inflammation may then cause stenosis or occlusion of the lumen and trigger ischemic events (Mourguet et al. 2019). Vasculitis is thus one of the promising causes of stroke (Schöberl et al. 2017).

Although the mechanisms of systemic vasculitis in patients with SARS-CoV-2 infection require further investigation using biopsies or autopsies, SARS-CoV-2 is able to induce endothelial dysfunction/exfoliation and endothelial/subendothelial inflammatory cell infiltration, which greatly increases the risk of thrombosis or hemorrhage in patients

\section{Downregulation of ACE2 leads to disruption of renin-angiotensin system}

ACE2, a homolog of ACE1, serves essential roles in reninangiotensin system (RAS: Fig. 2). Angiotensinogen is cleaved by Renin, which results in the formation of Ang I. Subsequently, Ang I is cleaved by ACE1, leading to the formation of Ang II which binds Ang II-type-1-receptor (AT1R), further inducing hypertension and atherosclerosis. In addition, ACE2 cleaves Ang II to form Ang 1-7 which promotes vasodilation and exerts anti-inflammatory/antiatherosclerosis effects through Mas receptor (MasR) (Packer and McMurray 2017; Paz Ocaranza et al. 2020; Stegbauer et al. 2019; Wu et al. 2020). Overexpression of ACE2 in vascular endothelial cells can affect the expression of endothelial nitric oxide synthase and production of nitric oxide by altering the ratio of Ang 1-7 to Ang II. These effects could protect brain tissues against ischemic damage (Chen et al. 2014) and prevent aneurysms by suppressing activation of RAS thus reducing the risk of hemorrhage (Hao et al. 2018). Furthermore, pathophysiologic changes involving the activation of RAS and depletion of ACE2 have been reported in cardiocerebrovascular diseases, and activation of ACE2 may have beneficial effects in hypertension, myocardial infarction, stroke, and atherosclerosis (Velkoska et al. 2016). Taken all together, these findings indicate that ACE2 serves key roles in cardiocerebrovascular protection through opposite regulation of the ACE1/Ang II/AT1R axis.
Fig. 2 Schematic chart of the renin-angiotensin system. Angiotensinogen is cleaved by Renin, which results in the formation of Ang I. Subsequently, Ang I is cleaved ACE1, leading to the formation of Ang II which binds AT1R, further inducing hypertension and atherosclerosis. ACE2 cleaves Ang II, which results in the formation of Ang 1-7 which promote vasodilation and exert anti-inflammatory/antiatherosclerosis effects through MasR. ACEI and ARB act on ACE1 and AT1R, respectively, subsequently inhibiting the ACE1/Ang II/AT1R axis

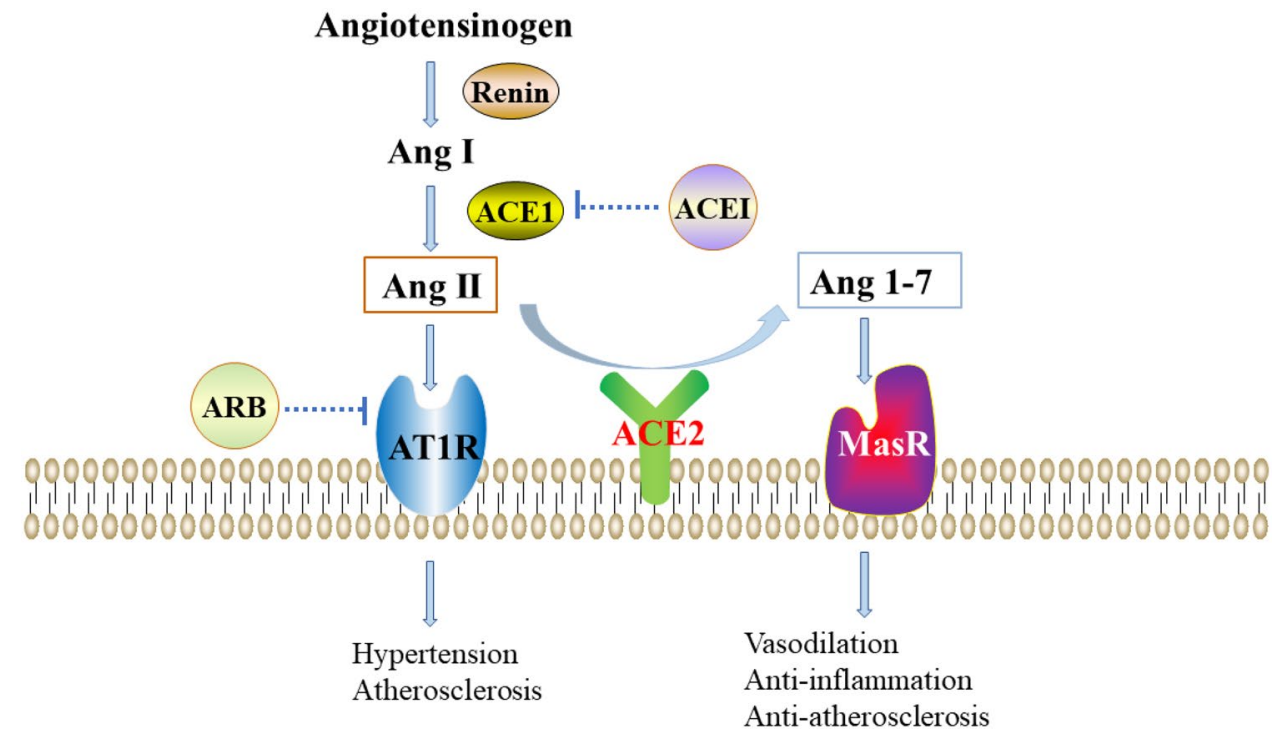


During the COVID-19 epidemic, Liu et al. have reported that plasma levels of Ang II are significantly increased in SARS-CoV-2-infected patients and are positively correlated with viral titer and disease severity (Liu et al. 2020). The accumulation of Ang II stimulates oxidative stress and further causes endothelial dysfunction (Janardhan et al. 2020). The dysregulation of RAS caused by SARS-CoV-2 infection may occur as spike protein interacts with the extracellular domain of ACE and triggers endocytosis to consume ACE2 on the surface of host cells, leading to the downregulation of ACE2 (Lan et al. 2020; Li et al. 2003; Turner et al. 2004). Interestingly, this interaction is significantly enhanced in patients with hypertension, coronary heart diseases, and diabetic conditions (Groß et al. 2020). In addition, reduced expression of ACE2 has been observed as the age increases, which is more common in men than in women (Xie et al. 2006). We hypothesized that endocytosis of ACE2 induced by virus together with agerelated reduction of ACE2 contributes the dysregulation of RAS and then leads to increased risk of CVD in COVID-19 patients, especially in elderly male patients with pre-existing chronic conditions such as hypertension or diabetes.

\section{Neutrophil extracellular traps (NETs) are the key factors of immunothrombosis}

Activated leukocytes interact with platelets and plasma clotting factors to form microthrombus, which is called immunothrombosis (Engelmann and Massberg 2013). Due to the existence of transparent microthrombus in multiple organs such as the heart, lungs, and kidneys of SARS-CoV2-infected patients (National Health Commission of the People's Republic of China 2020), Nicolai et al. suggested that neutrophils, immunogenic platelets, and dysregulated coagulation cascade could promote immunothrombosis, which is closely related to systemic hypercoagulability and acute respiratory distress syndrome in COVID-19 patients (Nicolai et al. 2020). These microthrombus are mainly composed of platelets, fibrin, and a large number of citrullinated histone $\mathrm{H} 3$ (citH3)-positive neutrophils (Middleton et al. 2020; Nicolai et al. 2020). citH3 is a biomarker of neutrophil extracellular traps (NETs) formation (Mauracher et al. 2018).

Previous studies have revealed the pathogenic roles of NETs on various thrombotic inflammatory states including sepsis (Chen et al. 2018; McDonald et al. 2017), thrombosis (Mauracher et al. ), and respiratory failure (Ojima et al. 2020). The formation of NETs may also trigger immunothrombosis in SARS-CoV-2 infection. Furthermore, Zuo et al. (Zuo et al. 2020) and Middleton et al. (Middleton et al. 2020) have suggested that COVID19 patients, especially those admitted to intensive care unit or receiving tracheal intubation or who died, exhibit significantly increased NETs levels. Therefore, the levels of NETs could be associated with the severity of this disease.

Activated platelets are the major initiator which can induce the activation of neutrophils and formation of NETs (Gaertner et al. 2017). Pathogens including virus could cause serial functional reactions through the activation of platelet-activating factor receptors such as toll-like receptor, further inducing platelet-neutrophil interactions, leading to the production of NETs and promoting thrombosis (Clark et al. 2007; Hottz et al. 2018). Moreover, numerous chemokines including platelet factor 4 (PF4) could promote the recruitment of white blood cells (WBCs) toward vascular injury or inflammatory sites (Hottz et al. 2018). In addition, activated platelets express P-selectin and glycoprotein (GP)-Ib, which interact with the P-selectin glycoprotein ligand 1 and the integrin Mac-1 on neutrophil membrane, respectively, to gain the stable adhesion and trigger the release of NETs (Etulain et al. 2015; Gaertner et al. 2017). During this process, PF4 binds to NETs, which increase the density and resistance to DNase of platelet-neutrophil aggregates. Meanwhile, PF4/NET-positive feedback loop is activated, which could maintain a coagulative NETs cascade response (Malisch et al. 2018).

The pathogens activate platelets in the host to induce the formation of NETs, subsequently promoting the formation of immune-related microthrombus. Increased levels of PF4 and NETs are detected in patients with novel coronavirus pneumonia, which are associated with multiple organ failure and systemic hypercoagulability (Middleton et al. 2020), perhaps being one of the reasons of thrombotic events in COVID-19 patients.

\section{Severe inflammation is one of the clinical features of COVID-19}

"Sepsis-induced coagulopathy" (SIC), a precursor state of disseminated intravascular coagulation (DIC) with elevated D-dimer and fibrinogen levels, could be one of the emerging features of severe COVID-19. It could be associated with infection-induced systemic inflammatory response, endothelial dysfunction, and microthrombosis (Hess et al. 2020). Most COVID-19 patients, especially those with severe symptoms, exhibit remarkable inflammatory responses with prolonged prothrombin time, elevated levels of C-reactive protein (CRP), and upregulation of inflammatory cytokines such as tumor necrosis factoralpha (TNF- $\alpha$ ) and various interleukins (ILs) (Chen et al. 2020; Guan et al. 2020a, b; Huang et al. 2020; Mehta et al. 2020; Wang et al. 2020; Warren-Gash et al. 2018). Middleton et al. have revealed significant elevation of IL-6 and IL-8, two additional cytokines probably related to the enhanced platelet reactivity and induction of WBCs to form NETs. These findings can be supported by the results of an 
in vitro assay, as the plasma from SARS-CoV-2-infected patients could induce the formation of NETs generated from neutrophils isolated from healthy people, while the plasma from healthy adults could not (Middleton et al. 2020). As mentioned above, the formation of NETs is closely associated with the prethrombotic state in COVID19 patients.

In addition, pathogens can be recognized by the pattern recognition receptor on the surface of human immune cells, which triggers systemic inflammation (Wallet et al. 2018), and these effects could last for a long term even after the recovery from the disease (Yende et al. 2008). Atherosclerosis, a wide range of chronic inflammatory lesions of the arterial wall, could be induced by this longterm inflammatory stimulation (Stojanović et al. 2020). Apart from long-term stimulation, acute infection-induced inflammatory response can also aggravate local inflammation in atherosclerotic plaques, which in turn destroys the stability of plaques and leads to rupture (Madjid et al. 2007; Naghavi et al. 2003). The subsequent aggregation and activation of platelets on the surface of ruptured plaques followed by secondary thrombosis is one of the common pathophysiological mechanisms of acute ischemic stroke.

In summary, SARS-CoV-2 could induce inflammatory cascade, affect coagulation and fibrinolysis system, promote atherosclerosis, and influence plaque stability, consequently increasing the risk of CVD in COVID-19 patients. CRP, as an indicator of systemic inflammation, is also an independent predictor of all-cause death in patients with ischemic stroke (Huang et al. 2012). Therefore, the outcomes in patients with significantly elevated CRP, and D-dimer levels could be worse.

\section{Antiphospholipid antibodies and their complexes are detected in COVID-19 patients}

Antiphospholipid antibodies could target different phospholipid-binding protein antigens, including lupus anticoagulant, anticardiolipin, anti- $\beta 2$ glycoprotein 1 (anti$\beta 2 \mathrm{GP} 1$ ), and anti-prothrombin antibody, which are related to both arterial and venous thrombosis events (Mendoza-Pinto et al. 2018). APL antibodies have been detected in severely infectious patients (Asherson and Cervera 2003). Until now, upregulation of infection-related APL and thrombosis events have been documented in various infectious patients, especially in those infected with human immunodeficiency virus (Ramos-Casals et al. 2004) and hepatitis C virus (Rafai et al. 2006; Ramos-Casals et al. 2004).

There are two types of APL antibodies: "autoimmune" and "infectious" type. Apart from the presence in some healthy volunteers (de Groot and Urbanus 2012), anti$\beta 2 \mathrm{GP} 1$ antibody can also be induced by certain microbial pathogens (Blank et al. 2002). The mechanisms underlying the transformation of anti- $\beta 2 \mathrm{GP} 1$ antibody from normal to pathogenic state remain unclear, while infection might play a role (van Os et al. 2011). After binding with pathogenic phospholipids under the oxidative stress and systemic inflammatory state, the conformation of nonoxidized circular $\beta 2 \mathrm{GP} 1$ transforms into oxidized J-shaped $\beta 2 \mathrm{GP} 1$, the cryptic epitopes are exposed, which induce the formation of anti- $\beta 2 \mathrm{GP} 1-\beta 2 \mathrm{GP} 1$ complexes (Agar et al. 2010; Janardhan et al. 2020). These immune complexes activate platelet receptors, and then lead to platelet adhesion, secretion of granules, synthesis of thromboxane A2, and formation of blood clot finally (Ho et al. 2016; Li et al. 2010).

Although "infectious" APL antibodies are usually transient, antiphospholipid syndrome (APS) has been observed in COVID-19 patients who developed cerebral ischemia accompanied by coagulopathy, especially in the severe cases (Beyrouti et al. 2020; Goldberg et al. 2020; Zhang et al. 2020). Zhang et al. have reported three cases of COVID-19 patients with increased APL antibodies, and all of them develop multiple cerebral infarctions (Zhang et al. 2020). In addition, Beyrouti et al. (Beyrouti et al. 2020) and Goldberg et al. (Goldberg et al. 2020) have revealed similar findings. Nevertheless, the results of Borghi et al. (Borghi et al. 2020) and Devreese et al. (Devreese et al. 2020) indicated no obvious association between the increased APL antibodies and thrombosis in COVID-19 patients. Therefore, it is not clear whether the thrombotic events in COVID-19 patients are associated with the levels of APL antibodies and whether it is reasonable to routinely screen for these indicators. Further investigations are required to reveal the pathogenic relevance of APL antibodies to ischemic events.

\section{Hyperglycemia promotes the occurrence and development of atherosclerosis}

Chen et al. suggested that $\sim 52 \%$ of COVID-19 patients exhibit hyperglycemia (Chen et al. 2020). This could be attributed to the stress response. Acute infection, as a potential source of stress, can induce self-protective defense in the human body. For instance, more hyperglycemic hormones could be secreted, consequently aggravating insulin resistance and resulting in a significant increase in blood glucose (Malisch et al. 2018). In addition, some patients may have pre-existing diseases such as diabetes (Guan et al. 2020a, b; Huang et al. 2020; Wang D et al. 2020); the treatment with glucocorticoids could accelerate glucose catabolism and lead to hyperglycemia (Guan et al. 2020a, b).

A previous study has revealed that the prevalence of abnormal glucose regulation is $68.7 \%$ among all stroke patients in China (Jia et al. 2012). Diabetes is an independent risk factor for stroke, which is closely related 
to the mechanisms underlying hyperglycemia or glucose fluctuation, and it could promote the occurrence and development of atherosclerosis (Dahl-Jørgensen et al. 2005; Johnston et al. 2019; Poznyak et al. 2020). Hyperglycemia could induce the overexpression of reactive oxygen species (ROS) via the mitochondrial electron transport chain, resulting in increased oxidative stress (Marco et al. 2015; Yuan et al. 2019). ROS could further activate numerous events associated with the progression of atherosclerosis, including the formation of advanced glycation end-products (Watson et al. 2011), the protein kinase C pathway (Zuniga et al. 2017), and the polyol pathway (Ramasamy and Goldberg 2010). Additionally, excessive ROS increase the formation of oxidized low-density lipoprotein and promote insulin resistance, thus indirectly accelerating the inflammation in atherosclerosis (Yuan et al. 2019). Moreover, elevated blood glucose increases blood viscosity, promotes platelet adhesion and aggregation, and further alters blood flow state, consequently increasing the risk of thrombosis (Marini et al. 2017).

In a previous study of 185 deceased patients with SARS, all patients exhibited elevated levels of glucose at admission, with notably increased levels at the time of death $(\mathrm{Li} \mathrm{C}$ and Pan 2003). During the Middle East Respiratory Syndrome pandemic, a middle-aged female patient was infected with MERS-CoV and developed a massive spontaneous intracranial hemorrhage with no other risk factors for hemorrhage such as hypertension, vascular malformation, coagulation disorders, or antiplatelet aggregation therapy. Furthermore, the glucose level in this patient reached $25 \mathrm{mmol} / \mathrm{L}$ on the day prior to hemorrhage (Al-Hameed 2017). Therefore, hyperglycemia may also induce vascular events in COVID-19 patients through the abovementioned mechanisms, leading to unfavorable therapeutic outcomes.

\section{Acute psychological stress alters the state of coagulation and fibrinolysis}

During the pandemic, the vast majority of people are more or less under psychological stress. COVID-19 patients not only experience physical discomfort and side effects of medication, but also suffer loneliness, anxiety and depression due to social isolation, uncertainty of the virus, and the overwhelming news (Xiang et al. 2020). These changes, as superimposed stressors, could cause stress responses in many patients. According to an online survey on a total of 714 COVID-19 patients, $~ 96.2 \%$ of patients exhibit post-traumatic stress symptoms (Bo et al. 2020).

It has also been reported that acute psychological stress events have great impact on CVD (Koton et al. 2004; Prasad et al. 2020), and a case-crossover study suggested that stress is an independent trigger for stroke (Prasad et al. 2020). However, the association between acute psychological stress and CVD remains unclear. Previous studies have revealed that the expression and release of plasminogen activator inhibitor type-1 (PAI-1) is increased under physiologic and pathologic stress (Jiang et al. 2011; Kozak et al. 2016). PAI-1, a serine protease inhibitor, is the only inhibitor that interacts with tissue plasminogen activator (t-PA). This interaction leads to rapid inactivation of t-PA, and PAI- 1 could be an essential mediator in stress-related hypercoagulable state and thrombosis (Jiang et al. 2011). It is also reported that plasma PAI-1 is synthesized and released from the sympathetic-adrenal axis, and activation of this axis is considered as a characteristic of stress response (Issam et al. 2019). Therefore, there are some pathophysiologic connections within acute psychological stress, activation of the sympathetic-adrenal axis, altered fibrinolytic activity, and increased risk of thrombosis.

As a stressor that cannot be ignored, the COVID-19 outbreak could be associated with higher risk of CVD. Unfortunately, the levels of plasma PAI-1 are not routinely monitored in COVID-19 patients. Future studies with large sample size are required to further explore the relationship between CVD and acute stress and to elucidate the underlying pathophysiologic mechanisms.

\section{Rapid vascular recanalization for COVID-19 patients with sudden ischemic stroke}

Current guidelines recommend that intravenous recombinant tissue plasminogen activator (rt-PA) can be used in selected patients with acute ischemic stroke (AIS) within $3 \mathrm{~h}$ or in highly selected patients within 3-4.5 h of symptom onset or last known well (Powers et al. 2019). Leukocytosis and elevation of C-reactive protein/D-dimer are detected in patients with COVID-19 (Chen N et al. 2020; Guan et al. 2020a, b; Guan et al. 2020a, b; Huang et al. 2020; Mehta et al. 2020; Wang et al. 2020; Warren-Gash et al. 2018). Although these abnormalities are not absolute contraindications of intravenous thrombolysis (IVT), previous studies have revealed that leukocytosis and elevated $\mathrm{CRP}$ and D-dimer levels are more predictive for higher risk of hemorrhage transformation and higher mortality rate in AIS patients treated with rt-PA (Hsu et al. 2016; Sato et al. 2020; Tiainen et al. 2013). Data from 75 stroke centers in Italy have demonstrated that 1-month unfavorable outcomes in patients with stroke and COVID-19 who received IVT therapy are remarkably increased (Cappellari et al. 2020). However, a multicenter case study in the USA suggests that IVT may be safe and effective as it significantly improves the 24-h National Institutes of Health Stroke Scale (NIHSS) score without increasing systemic/symptomatic intracranial hemorrhage (Carneiro et al. 2020). The sample sizes are limited in both studies; thus, further investigation on larger 
cohort is required to confirm the existing findings. At the moment, it is not a rare event to treat AIS with rt-PA in COVID-19 patients (Cappellari et al. 2020; Carneiro et al. 2020; Co et al. 2020; Escalard et al. 2020; Sangalli et al. 2020), but no sufficient evidence could confirm the efficacy of this treatment, and no clear regulation is available to prohibit the use of rt-PA just due to the abnormal laboratory indicators. Therefore, clinicians should be aware of the inherent risk of rt-PA treatment for patients with COVID19 and stroke. Decision should be prudently made in clinical practice after the coagulation status in patients is carefully evaluated.

Additionally, for those who exceed the thrombolytic time window, endovascular thrombectomy (EVT) is also recommended to achieve vascular recanalization and protect potential salvageable tissues (Powers et al. 2019). In contrast, COVID-19 patients with large-vessel occlusions (LVOs) who treated with EVT exhibit higher discharge rate (47.1\%) compared with those without treatment (32.4\%) (de Havenon et al. 2020). However, compared with pre-epidemic cases with LVOs, COVID-19 with LVOs is more common in younger patients with higher NIHSS score, heavier thrombus load, more serial/multi-regional occlusions, lower first-pass effect, higher risk of clot rupture, distal migration, and vascular re-occlusions (Escalard et al. 2020; Pop et al. 2020; Wang et al. 2020), which may be associated with the hypercoagulability in COVID-19 patients. In addition, the use of stent device could be related to clot fragmentation, distal migration, and re-thrombosis, especially in COVID19 patients with endothelial dysfunction (Wang et al. 2020). In contrast, suction device may cause lighter endothelial damage (Peschillo et al. 2018). Therefore, thrombectomy device for endovascular stroke therapy should be carefully chosen in the treatment of COVID-19 patients.

\section{Implications and possible challenges in disease management}

\section{Upregulation/activation of ACE2 by ACEI/ARB}

Based on the abovementioned analyses, SARS-CoV-2 affects the expression of ACE2, which in turn leads to the dysregulation of RAS, aggravates lung injuries, and promotes the development of atherosclerosis. Angiotensin-converting enzyme inhibitor (ACEI) and angiotensin receptor blocker (ARB), two commonly used antihypertensive drugs, could upregulate the expression and increase the activity of ACE2 (Ferrario et al. 2005; Ishiyama et al. 2004; Soro-Paavonen et al. 2012). Notably, a multi-center study indicated that in hospitalized COVID19 patients with hypertension, treatment with ACEI/ARB was associated with lower risk of all-cause mortality (Zhang et al. 2020). Therefore, whether these drugs could be used to prevent acute lung injuries and reduce the risk of stroke in COVID-19 patients should be further investigated, especially in those with severe symptoms.

\section{Anti-inflammatory therapy is controversial}

SARS-CoV-2 induces a series of inflammatory cascades which are closely related to hypercoagulable state and thrombosis (Zhang et al. 2020). However, after balancing the risks and benefits, whether to conduct anti-inflammatory therapy is controversial (Isidori et al. 2020). At present, glucocorticoids are commonly used as anti-inflammatory drugs in patients with COVID-19 (Guan et al. 2020a, b; Wang D et al. 2020). Although glucocorticoids prevent inflammation and lung damage, they could delay the clearance of virus and increase the risk of secondary infection, especially in immunodeficient patients (Zhang et al. 2020). Therefore, the WHO coronavirus management guidelines do not recommend the use of corticosteroids in COVID-19 patients (Isidori et al. 2020). Future studies are required to verify the use of corticosteroids and other anti-inflammatory drugs in COVID-19 patients.

\section{Intervention of neonatal neutrophil extracellular trap inhibitor (nNIF)}

SARS-CoV-2, as an invasive pathogen, can induce the formation of NETs by activating platelets in host. Nevertheless, NETs can also induce excessive thrombotic inflammatory responses, leading to thrombosis and ischemic events in patients. Increased levels of NETs have been detected in COVID-19 patients, which are also associated with disease severity (Middleton et al. 2020; Zuo et al. 2020). In previous study, neonatal NETinhibitory factor (nNIF) is able to inhibit the formation of NETs, suggesting its therapeutic potential (Yost et al. 2016). Furthermore, in a cohort study conducted by Middleton et al., synthesized nNIF could significantly decrease the levels of NETs which are induced by COVID19 plasma in vitro (Middleton et al. 2020). Therefore, nNIF inhibits the formation of NETs and may be used in the treatment of COVID-19 patients.

\section{Close monitoring of the levels of blood glucose and D-dimer}

Elevation of D-dimer and glucose could increase the risk of CVD; therefore, it is imperative that the levels of D-dimer and glucose should be closely monitored 
and strictly controlled during the treatment of COVID19 patients. For patients in hypercoagulable state or at higher risk of embolism, proper use of anticoagulants or antithrombotic therapy could be beneficial (Bikdeli et al. 2020; Spyropoulos et al. 2020). Neurological examinations should also be conducted on a daily basis, especially in patients with severe symptoms. Once the patients exhibit the signs of ACVD, neurologists should be immediately become involved in the treatment and follow-up management.

\section{Prevention of acute stress response}

As the global outbreak, a major acute stressor could cause significant posttraumatic stress responses among most patients, which can bring long-term effects on cardiocerebral vessels through various mechanisms (Xiang et al. 2020), appropriate psychological intervention for patients, such as education, consultation, long-term follow-up, and evaluation, are urgently required for COVID-19 patients.

\section{Immediate treatments are necessary}

According to recent statistics analyses, the number of admission rate for ischemic cerebrovascular events is significantly decreased in many countries or regions (Hoyer et al. 2020; McConachie et al. 2020; Schlachetzki et al. 2020). This may be a consequence of social distancing measures and patients' fear of being infected if going to hospital. Correspondingly, the volume of IVT is remarkably reduced during the COVID-19 pandemic (Plumereau et al. 2020), while intra-hospital delays are increased in patients transferred for EVT (Yang et al. 2020). Therefore, it is necessary to raise public understanding of ACVD and awareness of seeking for emergency treatments.

\section{Conclusion}

Based on our current knowledge of COVID-19, patients with SARS-COV-2 infection, especially those with severe symptoms, are at higher risk for CVD. Unfavorable therapeutic outcomes are observed in COVID-19 patients who developed acute cerebrovascular events. The potential mechanisms include ACE2-mediated endothelium damage, downregulation of ACE2, acute infection-related inflammation and coagulopathy, formation of NETs and APL antibodies, hyperglycemia, and acute stress reaction. These are the risk factors of cardiocerebrovascular events in COVID-19 patients. In future clinical practice, upregulation/ activation of ACE2, inhibition of NETs, close monitoring for inflammation/blood glucose/coagulation state, and reducing the psychological stress should be considered as novel therapeutic approaches for the treatment of COVID19 with CVD.

Author contributions Manxue Lou reviewed the literatures and drafted the manuscript; Dezhi Yuan analyzed the literatures and corrected the manuscript; Shengtao Liao reviewed the manuscript and completed the figures; Linyan Tong designed the table and reviewed the article; Jinfang Li initiated the study, supervised the project and reviewed the final version of this manuscript. All the authors approved the final manuscript.

Funding The grant was received by Jinfang Li (grant no. 2021 MSXM339).

\section{Declarations}

Conflict of interest The authors declare that they have no competing interests.

\section{References}

Agar C, van Os GMA, Mörgelin M, Sprenger RR, Marquart JA, Urbanus RT, Derksen RHWM, Meijers JCM, de Groot PG (2010) Beta2-glycoprotein I can exist in 2 conformations: implications for our understanding of the antiphospholipid syndrome. Blood 116(8):1336-1343. https://doi.org/10.1182/blood-2009-12-260976

Al-Hameed FM (2017) Spontaneous intracranial hemorrhage in a patient with Middle East respiratory syndrome corona virus. Saudi Med J 38(2):196-200. https://doi.org/10.15537/smj.2017.2.16255

Al Saiegh F, Ghosh R, Leibold A, Avery MB, Schmidt RF, Theofanis T, Mouchtouris N, Philipp L, Peiper SC, Wang Z-X, Rincon F, Tjoumakaris SI, Jabbour P, Rosenwasser RH, Gooch MR (2020) Status of SARS-CoV-2 in cerebrospinal fluid of patients with COVID-19 and stroke. J Neurol Neurosurg Psychiatry. https:// doi.org/10.1136/jnnp-2020-323522

Asherson RA, Cervera R (2003) Antiphospholipid antibodies and infections. Ann Rheum Dis 62(5):388-393. https://doi. org/10.1136/ard.62.5.388

Avula A, Nalleballe K, Narula N, Sapozhnikov S, Dandu V, Toom S, Glaser A, Elsayegh D (2020) COVID-19 presenting as stroke. Brain Behav Immun. https://doi.org/10.1016/j.bbi.2020.04.077

Baig AM, Khaleeq A, Ali U, Syeda H (2020) Evidence of the COVID19 virus targeting the CNS: tissue distribution, host-virus interaction, and proposed neurotropic mechanisms. ACS Chem Neurosci 11(7):995-998. https://doi.org/10.1021/acschemneuro. Oc00122

Beyrouti R, Adams ME, Benjamin L, Cohen H, Farmer SF, Goh YY, Humphries F, Jäger HR, Losseff NA, Perry RJ, Shah S, Simister RJ, Turner D, Chandratheva A, Werring DJ (2020) Characteristics of ischaemic stroke associated with COVID-19. J Neurol Neurosurg Psychiatry. https://doi.org/10.1136/jnnp-2020-323586

Bikdeli B, Madhavan MV, Jimenez D, Chuich T, Dreyfus I, Driggin E, Nigoghossian CD, Ageno W, Madjid M, Guo Y, Tang LV, Hu Y, Giri J, Cushman M, Quéré I, Dimakakos EP, Gibson CM, Lippi G, Favaloro EJ, Fareed J, Caprini JA, Tafur AJ, Burton JR, Francese DP, Wang EY, Falanga A, McLintock C, Hunt BJ, Spyropoulos AC, Barnes GD, Eikelboom JW, Weinberg I, Schulman S, 
Carrier M, Piazza G, Beckman JA, Steg PG, Stone GW, Rosenkranz S, Goldhaber SZ, Parikh SA, Monreal M, Krumholz HM, Konstantinides SV, Weitz JI, Lip GYH (2020) COVID-19 and thrombotic or thromboembolic disease: implications for prevention, antithrombotic therapy, and follow-up. J Am Coll Cardiol. https://doi.org/10.1016/j.jacc.2020.04.031

Blank M, Krause I, Fridkin M, Keller N, Kopolovic J, Goldberg I, Tobar A, Shoenfeld Y (2002) Bacterial induction of autoantibodies to beta2-glycoprotein-I accounts for the infectious etiology of antiphospholipid syndrome. J Clin Investig 109(6):797-804. https:// doi.org/10.1172/JCI12337

Bo H-X, Li W, Yang Y, Wang Y, Zhang Q, Cheung T, Wu X and Xiang Y-T (2020) Posttraumatic stress symptoms and attitude toward crisis mental health services among clinically stable patients with COVID-19 in China. Psychol Med, 1-2. https://doi.org/10.1017/ S0033291720000999

Boehme AK, Esenwa C, Elkind MSV (2017) Stroke risk factors, genetics, and prevention. Circ Res 120(3):472-495. https://doi. org/10.1161/CIRCRESAHA.116.308398

Borghi MO, Beltagy A, Garrafa E, Curreli D, Cecchini G, Bodio C, Grossi C, Blengino S, Tincani A, Franceschini F, Andreoli L, Lazzaroni MG, Piantoni S, Masneri S, Crisafulli F, Brugnoni D, Muiesan ML, Salvetti M, Parati G, Torresani E, Mahler M, Heilbron F, Pregnolato F, Pengo M, Tedesco F, Pozzi N and Meroni PL (2020) Prevalence, specificity, and clinical association of anti-phospholipid antibodies in COVID-19 patients: are the antibodies really guilty? medRxiv : the preprint server for health sciences. https://doi.org/10.1101/2020.06.17.20134114

Cappellari M, Zini A, Sangalli D, Cavallini A, Reggiani M, Sepe FN, Rifino N, Giussani G, Guidetti D, Zedde M, Marcheselli S, Longoni M, Beretta S, Sidoti V, Papurello DM, Giossi A, Nencini P, Plocco M, Balestrino M, Rota E, Toni D (2020) Thrombolysis and bridging therapy in patients with acute ischaemic stroke and Covid-19. Eur J Neurol. https://doi.org/10.1111/ene.14511

Carneiro T, Dashkoff J, Leung LY, Nobleza COHS, Marulanda-Londono E, Hathidara M, Koch S, Sur N, Boske A, Voetsch B, Aboul Nour H, Miller DJ, Daneshmand A, Shulman J, Curiale G, Greer DM, Romero JR, Anand P, Cervantes-Arslanian AM (2020) Intravenous tPA for acute ischemic stroke in patients with COVID-19 Journal of stroke and cerebrovascular diseases. the official journal of National Stroke Association 29(11):105201. https://doi.org/10.1016/j. jstrokecerebrovasdis.2020.105201

Chan JF-W, Yuan S, Kok K-H, To KK-W, Chu H, Yang J, Xing F, Liu J, Yip CC-Y, Poon RW-S, Tsoi H-W, Lo SK-F, Chan K-H, Poon VK-M, Chan W-M, Ip JD, Cai J-P, Cheng VC-C, Chen H, Hui CK-M, Yuen K-Y (2020) A familial cluster of pneumonia associated with the 2019 novel coronavirus indicating person-toperson transmission: a study of a family cluster. Lancet (London, England) 395(10223):514-523. https://doi.org/10.1016/S01406736(20)30154-9

Chatzizisis YS, Coskun AU, Jonas M, Edelman ER, Feldman CL, Stone PH (2007) Role of endothelial shear stress in the natural history of coronary atherosclerosis and vascular remodeling: molecular, cellular, and vascular behavior. J Am Coll Cardiol 49(25):23792393. https://doi.org/10.1016/j.jacc.2007.02.059

Chen J, Zhao Y, Chen S, Wang J, Xiao X, Ma X, Penchikala M, Xia H, Lazartigues E, Zhao B, Chen Y (2014) Neuronal overexpression of ACE2 protects brain from ischemia-induced damage. Neuropharmacology 79:550-558. https://doi.org/10.1016/j. neuropharm.2014.01.004

Chen L, Zhao Y, Lai D, Zhang P, Yang Y, Li Y, Fei K, Jiang G, Fan J (2018) Neutrophil extracellular traps promote macrophage pyroptosis in sepsis. Cell death \& disease 9(6):597. https://doi. org/10.1038/s41419-018-0538-5

Chen N, Zhou M, Dong X, Qu J, Gong F, Han Y, Qiu Y, Wang J, Liu Y, Wei Y, Xia Ja YuT, Zhang X, Zhang L (2020)
Epidemiological and clinical characteristics of 99 cases of 2019 novel coronavirus pneumonia in Wuhan, China: a descriptive study. Lancet (London, England) 395(10223):507-513. https:// doi.org/10.1016/S0140-6736(20)30211-7

Clark SR, Ma AC, Tavener SA, McDonald B, Goodarzi Z, Kelly MM, Patel KD, Chakrabarti S, McAvoy E, Sinclair GD, Keys EM, Allen-Vercoe E, Devinney R, Doig CJ, Green FHY, Kubes P (2007) Platelet TLR4 activates neutrophil extracellular traps to ensnare bacteria in septic blood. Nat Med 13(4):463-469. https:// doi.org/10.1038/nm1565

Co COC, Yu JRT, Laxamana LC, David-Ona DIA (2020) Intravenous thrombolysis for stroke in a COVID-19 positive filipino patient, a case report Journal of clinical neuroscience. : official journal of the Neurosurgical Society of Australasia 77:234-236. https:// doi.org/10.1016/j.jocn.2020.05.006

Dahl-Jørgensen K, Larsen JR, Hanssen KF (2005) Atherosclerosis in childhood and adolescent type 1 diabetes: early disease, early treatment? Diabetologia 48(8):1445-1453. https://doi. org/10.1007/s00125-005-1832-1

de Groot PG, Urbanus RT (2012) The significance of autoantibodies against $\beta 2$-glycoprotein I. Blood 120(2):266-274. https://doi. org/10.1182/blood-2012-03-378646

de Havenon A, Yaghi S, Mistry EA, Delic A, Hohmann S, Shippey E, Stulberg E, Tirschwell D, Frontera JA, Petersen NH, Anadani M (2020) Endovascular thrombectomy in acute ischemic stroke patients with COVID-19: prevalence, demographics, and outcomes. Journal of neurointerventional surgery 12(11):10451048. https://doi.org/10.1136/neurintsurg-2020-016777

Devreese KMJ, Linskens EA, Benoit D and Peperstraete H (2020) Antiphospholipid antibodies in patients with COVID-19: a relevant observation? J Thromb Haemost : JTH. https://doi. org/10.1111/jth.14994

Di Marco E, Jha JC, Sharma A, Wilkinson-Berka JL, Jandeleit-Dahm KA and de Haan JB (2015) Are reactive oxygen species still the basis for diabetic complications? Clinical science (London, England : 1979) 129(2), 199-216. https://doi.org/10.1042/CS20150093

Ding Y, Wang H, Shen H, Li Z, Geng J, Han H, Cai J, Li X, Kang W, Weng D, Lu Y, Wu D, He L, Yao K (2003) The clinical pathology of severe acute respiratory syndrome (SARS): a report from China. J Pathol 200(3):282-289. https://doi.org/10.1002/ path. 1440

Engelmann B, Massberg S (2013) Thrombosis as an intravascular effector of innate immunity. Nat Rev Immunol 13(1):34-45. https:// doi.org/10.1038/nri3345

Escalard S, Maïer B, Redjem H, Delvoye F, Hébert S, Smajda S, Ciccio G, Desilles J-P, Mazighi M, Blanc R, Piotin M (2020) Treatment of acute ischemic stroke due to large vessel occlusion with COVID-19: experience from Paris. Stroke 51(8):2540-2543. https://doi.org/10.1161/STROKEAHA.120.030574

Etulain J, Martinod K, Wong SL, Cifuni SM, Schattner M, Wagner DD (2015) P-selectin promotes neutrophil extracellular trap formation in mice. Blood 126(2):242-246. https://doi. org/10.1182/blood-2015-01-624023

Ferrario CM, Jessup J, Chappell MC, Averill DB, Brosnihan KB, Tallant EA, Diz DI, Gallagher PE (2005) Effect of angiotensin-converting enzyme inhibition and angiotensin II receptor blockers on cardiac angiotensin-converting enzyme 2. Circulation 111(20):2605-2610. https://doi.org/10.1161/ CIRCULATIONAHA.104.510461

Fung TS, Liu DX (2019) Human coronavirus: host-pathogen interaction. Annu Rev Microbiol 73:529-557. https://doi. org/10.1146/annurev-micro-020518-115759

Gaertner F, Ahmad Z, Rosenberger G, Fan S, Nicolai L, Busch B, Yavuz G, Luckner M, Ishikawa-Ankerhold H, Hennel R, Benechet A, Lorenz M, Chandraratne S, Schubert I, Helmer S, Striednig B, Stark K, Janko M, Böttcher RT, Verschoor A, 
Leon C, Gachet C, Gudermann T, Mederos Y Schnitzler M, Pincus Z, Iannacone M, Haas R, Wanner G, Lauber K, Sixt $M$ and Massberg S (2017) Migrating platelets are mechanoscavengers that collect and bundle bacteria. Cell 171(6). https:// doi.org/10.1016/j.cell.2017.11.001

Goldberg MF, Goldberg MF, Cerejo R, Tayal AH (2020) Cerebrovascular disease in COVID-19. American journal of neuroradiology, AJNR. https://doi.org/10.3174/ajnr.A6588

Groß S, Jahn C, Cushman S, Bär C, Thum T (2020) SARS-CoV-2 receptor ACE2-dependent implications on the cardiovascular system: from basic science to clinical implications. J Mol Cell Cardiol. https://doi.org/10.1016/j.yjmcc.2020.04.031

Guan WJ, Ni ZY, Hu Y, Liang WH, Ou CQ, He JX, Liu L, Shan H, Lei CL, Hui DSC, Du B, Li LJ, Zeng G, Yuen KY, Chen RC, Tang CL, Wang T, Chen PY, Xiang J, Li SY, Wang JL, Liang ZJ, Peng YX, Wei L, Liu Y, Hu YH, Peng P, Wang JM, Liu JY, Chen Z, Li G, Zheng ZJ, Qiu SQ, Luo J, Ye CJ, Zhu SY, Zhong NS (2020) Clinical characteristics of coronavirus disease 2019 in China. N Engl J Med. https://doi.org/10.1056/NEJMoa2002032

Guan WJ, Ni ZY, Hu Y, Liang WH, Ou CQ, He JX, Liu L, Shan H, Lei CL, Hui DSC, Du B, Li LJ, Zeng G, Yuen KY, Chen RC, Tang CL, Wang T, Chen PY, Xiang J, Li SY, Wang JL, Liang ZJ, Peng YX, Wei L, Liu Y, Hu YH, Peng P, Wang JM, Liu JY, Chen Z, Li G, Zheng ZJ, Qiu SQ, Luo J, Ye CJ, Zhu SY, Zhong NS (2020) Clinical characteristics of coronavirus disease 2019 in China. N Engl J Med 382(18):1708-1720. https://doi.org/10.1056/ NEJMoa2002032

Hao Q, Dong X, Chen X, Yan F, Wang X, Shi H, Dong B (2018) Angiotensin-converting Enzyme 2 inhibits angiotensin II-induced abdominal aortic aneurysms in mice. Hum Gene Ther. https://doi.org/10.1089/hum.2016.144

Hess DC, Eldahshan W, Rutkowski E (2020) COVID-19-related stroke. Transl Stroke Res. https://doi.org/10.1007/s12975-020-00818-9

Ho YC, Ahuja KDK, Körner H and Adams MJ (2016) $\beta \mathrm{GP} 1$, Anti- $\beta$ GP1 antibodies and platelets: key players in the antiphospholipid syndrome. Antibodies (Basel, Switzerland) 5(2). https://doi.org/10.3390/antib5020012

Hottz ED, Bozza FA, Bozza PT (2018) Platelets in immune response to virus and immunopathology of viral infections. Front Med 5:121. https://doi.org/10.3389/fmed.2018.00121

Hoyer C, Ebert A, Huttner HB, Puetz V, Kallmünzer B, Barlinn K, Haverkamp C, Harloff A, Brich J, Platten M, Szabo K (2020) Acute stroke in times of the COVID-19 pandemic: a multicenter study. Stroke 51(7):2224-2227. https://doi.org/10.1161/ STROKEAHA.120.030395

Hsu P-J, Chen C-H, Yeh S-J, Tsai L-K, Tang S-C, Jeng J-S (2016) High plasma D-Dimer indicates unfavorable outcome of acute ischemic stroke patients receiving intravenous thrombolysis. Cerebrovasc Dis (Basel, Switzerland) 42(1-2):117-121. https:// doi.org/10.1159/000445037

Hu S-s, Yang Y-j, Zhu M-1, Chen Z, Zou Z-p, He J-g, Y-f Wu, Han D-m (2004) Effects of underlying cerebrocardiovascular diseases on the incidence of critical conditions and multiple organs dysfunction syndrome in severe acute respiratory syndrome cases. Zhonghua yi xue za zhi 84(15):1257-1259. https://doi. org/10.3760/j:issn:0376-2491.2004.15.007

Huang C, Wang Y, Li X, Ren L, Zhao J, Hu Y, Zhang L, Fan G, Xu J, Gu X, Cheng Z, Yu T, Xia J, Wei Y, Wu W, Xie X, Yin W, Li H, Liu M, Xiao Y, Gao H, Guo L, Xie J, Wang G, Jiang R, Gao Z, Jin Q, Wang J, Cao B (2020) Clinical features of patients infected with 2019 novel coronavirus in Wuhan, China. Lancet (London, England) 395(10223):497-506. https://doi.org/10.1016/S01406736(20)30183-5

Huang Y, Jing J, Zhao X-Q, Wang C-X, Wang Y-L, Liu G-F, Wang C-J, Liu L-P, Yang X-M, Jiao Y, Jiao Y, Wang L-S, Wang Y-J, $\mathrm{Gu} \mathrm{W}-\mathrm{K}$ (2012) High-sensitivity C-reactive protein is a strong risk factor for death after acute ischemic stroke among Chinese. CNS Neurosci Ther 18(3):261-266. https://doi.org/10.1111/ j.1755-5949.2012.00296.x

Ishiyama Y, Gallagher PE, Averill DB, Tallant EA, Brosnihan KB and Ferrario CM (2004) Upregulation of angiotensin-converting enzyme 2 after myocardial infarction by blockade of angiotensin II receptors. Hypertension (Dallas, Tex. : 1979) 43(5), 970-976. https://doi.org/10.1161/01.HYP.0000124667.34652.1a

Isidori AM, Pofi R, Hasenmajer V, Lenzi A, Pivonello R (2020) Use of glucocorticoids in patients with adrenal insufficiency and COVID-19 infection. Diabetes \& endocrinology, The lancet. https://doi.org/10.1016/S2213-8587(20)30149-2

Issam N, Allan F, A LJ-M, Abdelkrim T, Amalia T and Maâmar S (2019) Stress as an immunomodulator: liver $\mathrm{X}$ receptors maybe the answer. Inflammopharmacology 27(1). https://doi. org/10.1007/s10787-018-0546-1

Janardhan V, Janardhan V, Kalousek V (2020) COVID-19 as a blood clotting disorder masquerading as a respiratory illness: a cerebrovascular perspective and therapeutic implications for stroke thrombectomy Journal of neuroimaging. : official journal of the American Society of Neuroimaging 30(5):555-561. https:// doi.org/10.1111/jon.12770

Jia Q, Zheng H, Zhao X, Wang C, Liu G, Wang Y, Liu L, Li H, Zhong L, Wang Y (2012) Abnormal glucose regulation in patients with acute stroke across China: prevalence and baseline patient characteristics. Stroke 43(3):650-657. https://doi.org/10.1161/ STROKEAHA.111.633784

Jiang Q, Gingles NA, Olivier MA, Miles LA, Parmer RJ (2011) The anti-fibrinolytic SERPIN, plasminogen activator inhibitor 1 (PAI-1), is targeted to and released from catecholamine storage vesicles. Blood 117(26):7155-7163. https://doi.org/10.1182/ blood-2010-05-287672

Johnston KC, Bruno A, Pauls Q, Hall CE, Barrett KM, Barsan W, Fansler A, Van de Bruinhorst K, Janis S, Durkalski-Mauldin VL (2019) Intensive vs standard treatment of hyperglycemia and functional outcome in patients with acute ischemic stroke: the SHINE randomized clinical trial. JAMA 322(4):326-335. https:// doi.org/10.1001/jama.2019.9346

Koton S, Tanne D, Bornstein NM, Green MS (2004) Triggering risk factors for ischemic stroke: a case-crossover study. Neurology 63(11):2006-2010. https://doi.org/10.1212/01.wnl.0000145842. 25520.a2

Kozak HH, Uca AU, Altaş M (2016) Is acute stress and plasminogen activator inhibitor polymorphism associated with acute ischemic stroke? Clin Neurol Neurosurg 143:159-160. https://doi. org/10.1016/j.clineuro.2015.11.015

Lan J, Ge J, Yu J, Shan S, Zhou H, Fan S, Zhang Q, Shi X, Wang Q, Zhang L, Wang X (2020) Structure of the SARS-CoV-2 spike receptor-binding domain bound to the ACE2 receptor. Nature. https://doi.org/10.1038/s41586-020-2180-5

Li C and Pan S (2003) Analysis and causation discussion of 185 severe acute respiratory syndrome dead cases. Zhongguo wei zhong bing ji jiu yi xue $=$ Chinese critical care medicine $=$ Zhongguo weizhongbing jijiuyixue 15(10), 582-584. Retrieved from https:// pubmed.ncbi.nlm.nih.gov/14552675

Li W, Moore MJ, Vasilieva N, Sui J, Wong SK, Berne MA, Somasundaran M, Sullivan JL, Luzuriaga K, Greenough TC, Choe H, Farzan M (2003) Angiotensin-converting enzyme 2 is a functional receptor for the SARS coronavirus. Nature 426(6965):450-454. https://doi.org/10.1038/nature02145

Li Z, Delaney MK, O'Brien KA, Du X (2010) Signaling during platelet adhesion and activation. Arterioscler Thromb Vasc Biol 30(12):2341-2349. https://doi.org/10.1161/ATVBAHA.110.207522

Liberman AL, Nagel MA, Hurley MC, Caprio FZ, Bernstein RA, Gilden D (2014) Rapid development of 9 cerebral aneurysms 
in varicella-zoster virus vasculopathy. Neurology 82(23):21392141. https://doi.org/10.1212/WNL.0000000000000503

Liu Y, Yang Y, Zhang C, Huang F, Wang F, Yuan J, Wang Z, Li J, Li J, Feng C, Zhang Z, Wang L, Peng L, Chen L, Qin Y, Zhao D, Tan S, Yin L, Xu J, Zhou C, Jiang C, Liu L (2020) Clinical and biochemical indexes from 2019-nCoV infected patients linked to viral loads and lung injury. Sci China Life Sci 63(3):364-374. https://doi.org/10.1007/s11427-020-1643-8

Lu R, Zhao X, Li J, Niu P, Yang B, Wu H, Wang W, Song H, Huang B, Zhu N, Bi Y, Ma X, Zhan F, Wang L, Hu T, Zhou H, Hu Z, Zhou W, Zhao L, Chen J, Meng Y, Wang J, Lin Y, Yuan J, Xie Z, Ma J, Liu WJ, Wang D, Xu W, Holmes EC, Gao GF, Wu G, Chen W, Shi W, Tan W (2020) Genomic characterisation and epidemiology of 2019 novel coronavirus: implications for virus origins and receptor binding. Lancet (London, England) 395(10224):565574. https://doi.org/10.1016/S0140-6736(20)30251-8

Madjid M, Safavi-Naeini P, Solomon SD, Vardeny O (2020) Potential effects of coronaviruses on the cardiovascular system: a review. JAMA cardiology. https://doi.org/10.1001/jamacardio.2020.1286

Madjid M, Vela D, Khalili-Tabrizi H, Casscells SW and Litovsky S (2007) Systemic infections cause exaggerated local inflammation in atherosclerotic coronary arteries: clues to the triggering effect of acute infections on acute coronary syndromes. Tex Heart Inst J 34(1), 11-18. Retrieved from https://pubmed.ncbi.nlm.nih. gov/17420787

Malisch JL, Bennett DJ, Davidson BA, Wenker EE, Suzich RN, Johnson EE (2018) Stress-Induced hyperglycemia in white-throated and white-crowned sparrows: a new technique for rapid glucose measurement in the field. Physiol Biochem Zool 91(4):943-949. https://doi.org/10.1086/698536

Mao L, Jin H, Wang M, Hu Y, Chen S, He Q, Chang J, Hong C, Zhou Y, Wang D, Miao X, Li Y, Hu B (2020) Neurologic manifestations of hospitalized patients with coronavirus disease 2019 in Wuhan. JAMA neurology, China. https://doi.org/10.1001/jamaneurol. 2020.1127

Marini MA, Fiorentino TV, Andreozzi F, Mannino GC, Perticone M, Sciacqua A, Perticone F, Sesti G (2017) Elevated 1-h postchallenge plasma glucose levels in subjects with normal glucose tolerance or impaired glucose tolerance are associated with whole blood viscosity. Acta Diabetol 54(8):775-784. https://doi. org/10.1007/s00592-017-1004-z

Mauracher LM, Posch F, Martinod K, Grilz E, Däullary T, Hell L, Brostjan C, Zielinski C, Ay C, Wagner DD, Pabinger I, Thaler J (2018) Citrullinated histone H3, a biomarker of neutrophil extracellular trap formation, predicts the risk of venous thromboembolism in cancer patients. J Thromb Haemost 16(3):508-518. https://doi.org/10.1111/jth.13951

McConachie D, McConachie N, White P, Crossley R and Izzath W (2020) Mechanical thrombectomy for acute ischaemic stroke during the COVID-19 pandemic: changes to UK practice and lessons learned. Clin Radiol 75(10). https://doi.org/10.1016/j. crad.2020.07.001

McDonald B, Davis RP, Kim S-J, Tse M, Esmon CT, Kolaczkowska E, Jenne CN (2017) Platelets and neutrophil extracellular traps collaborate to promote intravascular coagulation during sepsis in mice. Blood 129(10):1357-1367. https://doi.org/10.1182/blood2016-09-741298

Mehta P, McAuley DF, Brown M, Sanchez E, Tattersall RS, Manson JJ (2020) COVID-19: consider cytokine storm syndromes and immunosuppression. Lancet (London, England) 395(10229):1033-1034. https://doi.org/10.1016/S01406736(20)30628-0

Mendoza-Pinto C, García-Carrasco M, Cervera R (2018) Role of infectious diseases in the antiphospholipid syndrome (including its catastrophic variant). Curr Rheumatol Rep 20(10):62. https:// doi.org/10.1007/s11926-018-0773-x
Middleton EA, He X-Y, Denorme F, Campbell RA, Ng D, Salvatore SP, Mostyka M, Baxter-Stoltzfus A, Borczuk AC, Loda M, Cody MJ, Manne BK, Portier I, Harris ES, Petrey AC, Beswick EJ, Caulin AF, Iovino A, Abegglen LM, Weyrich AS, Rondina MT, Egeblad M, Schiffman JD, Yost CC (2020) Neutrophil extracellular traps contribute to immunothrombosis in COVID-19 acute respiratory distress syndrome. Blood 136(10):1169-1179. https://doi. org/10.1182/blood.2020007008

Mourguet M, Chauveau D, Faguer S, Ruidavets JB, Béjot Y, Ribes D, Huart A, Alric L, Balardy L, Astudillo L, Adoue D, Sailler L, Pugnet G (2019) Increased ischemic stroke, acute coronary artery disease and mortality in patients with granulomatosis with polyangiitis and microscopic polyangiitis. J Autoimmun 96:134141. https://doi.org/10.1016/j.jaut.2018.09.004

Naghavi M, Wyde P, Litovsky S, Madjid M, Akhtar A, Naguib S, Siadaty MS, Sanati S, Casscells W (2003) Influenza infection exerts prominent inflammatory and thrombotic effects on the atherosclerotic plaques of apolipoprotein E-deficient mice. Circulation 107(5):762-768. https://doi.org/10.1161/01. cir.0000048190.68071.2b

National Health Commission of the People's Republic of China (2020) Diagnosis and treatment of corona virus disease-19 (8th trial edition). World J Clin Infect Dis 13(05), 321-328.

Nicolai L, Leunig A, Brambs S, Kaiser R, Weinberger T, Weigand M, Muenchhoff M, Hellmuth JC, Ledderose S, Schulz H, Scherer C, Rudelius M, Zoller M, Höchter D, Keppler O, Teupser D, Zwißler B, von Bergwelt-Baildon M, Kääb S, Massberg S, Pekayvaz K, Stark K (2020) Immunothrombotic dysregulation in COVID-19 pneumonia is associated with respiratory failure and coagulopathy. Circulation 142(12):1176-1189. https://doi. org/10.1161/CIRCULATIONAHA.120.048488

Novel Coronavirus Pneumonia Emergency Response Epidemiology Team (2020) The epidemiological characteristics of an outbreak of 2019 novel coronavirus diseases (COVID-19) in China. Zhonghua Liu Xing Bing Xue Za Zhi 41(2):145-151. https:// doi.org/10.3760/cma.j.issn.0254-6450.2020.02.003

Oboho IK, Tomczyk SM, Al-Asmari AM, Banjar AA, Al-Mugti H, Aloraini MS, Alkhaldi KZ, Almohammadi EL, Alraddadi BM, Gerber SI, Swerdlow DL, Watson JT, Madani TA (2015) 2014 MERS-CoV outbreak in Jeddah-a link to health care facilities. N Eng J Med 372(9):846-854. https://doi.org/10.1056/ NEJMoa1408636

Ojima M, Yamamoto N, Hirose T, Hamaguchi S, Tasaki O, Kojima T, Tomono K, Ogura H, Shimazu T (2020) Serial change of neutrophil extracellular traps in tracheal aspirate of patients with acute respiratory distress syndrome: report of three cases. J Intensive Care 8:25. https://doi.org/10.1186/s40560-020-00444-5

Oxley TJ, Mocco J, Majidi S, Kellner CP, Shoirah H, Singh IP, De Leacy RA, Shigematsu T, Ladner TR, Yaeger KA, Skliut M, Weinberger J, Dangayach NS, Bederson JB, Tuhrim S, Fifi JT (2020) Large-vessel stroke as a presenting feature of Covid-19 in the young. N Eng J Med 382(20):e60. https://doi.org/10.1056/ NEJMc2009787

Packer M, McMurray JJV (2017) Importance of endogenous compensatory vasoactive peptides in broadening the effects of inhibitors of the renin-angiotensin system for the treatment of heart failure. Lancet (London, England) 389(10081):1831-1840. https://doi.org/10.1016/S0140-6736(16)30969-2

Paniz-Mondolfi A, Bryce C, Grimes Z, Gordon RE, Reidy J, Lednicky J, Sordillo EM, Fowkes M (2020) Central nervous system involvement by severe acute respiratory syndrome coronavirus-2 (SARS-CoV-2). J Med Virol. https://doi.org/10.1002/jmv.25915

Paz Ocaranza M, Riquelme JA, García L, Jalil JE, Chiong M, Santos RAS, Lavandero S (2020) Counter-regulatory renin-angiotensin system in cardiovascular disease. Nat Rev Cardiol 17(2):116129. https://doi.org/10.1038/s41569-019-0244-8 
Peiris JSM, Lai ST, Poon LLM, Guan Y, Yam LYC, Lim W, Nicholls J, Yee WKS, Yan WW, Cheung MT, Cheng VCC, Chan KH, Tsang DNC, Yung RWH, Ng TK, Yuen KY (2003) Coronavirus as a possible cause of severe acute respiratory syndrome. Lancet (London, England) 361(9366):1319-1325. https://doi. org/10.1016/s0140-6736(03)13077-2

Peschillo S, Tomasello A, Diana F, Hernandez D, Toccaceli G, RosalFontana M, Esteves Coelho M, Missori P (2018) Comparison of subacute vascular damage caused by ADAPT versus stent retriever devices after thrombectomy in acute ischemic stroke: histological and ultrastructural study in an animal model. Interv Neurol 7(6):501-512. https://doi.org/10.1159/000491028

Plumereau C, Cho T-H, Buisson M, Amaz C, Cappucci M, Derex L, Ong E, Fontaine J, Rascle L, Riva R, Schiavo D, Benhamed A, Douplat M, Bony T, Tazarourte K, Tuttle C, Eker OF, Berthezène Y, Ovize M, Nighoghossian N, Mechtouff L (2020) Effect of the COVID-19 pandemic on acute stroke reperfusion therapy: data from the Lyon Stroke Center Network. J Neurol. https://doi. org/10.1007/s00415-020-10199-6

Pop R, Hasiu A, Bolognini F, Mihoc D, Quenardelle V, Gheoca R, Schluck E, Courtois S, Delaitre M, Musacchio M, Pottecher J, Chamaraux-Tran TN, Sellal F, Wolff V, Lebedinsky PA, Beaujeux R (2020) Stroke thrombectomy in patients with COVID-19: initial experience in 13 cases. Am J Neuroradiol . https://doi.org/10.3174/ajnr.A6750

Poredos P, Jezovnik MK (2018) Endothelial dysfunction and venous thrombosis. Angiology 69(7):564-567. https://doi. org/10.1177/0003319717732238

Powers WJ, Rabinstein AA, Ackerson T, Adeoye OM, Bambakidis NC, Becker K, Biller J, Brown M, Demaerschalk BM, Hoh B, Jauch EC, Kidwell CS, Leslie-Mazwi TM, Ovbiagele B, Scott PA, Sheth KN, Southerland AM, Summers DV, Tirschwell DL (2019) Guidelines for the early management of patients with acute ischemic stroke: 2019 Update to the 2018 guidelines for the early management of acute ischemic stroke: a guideline for healthcare professionals from the American Heart Association/ American Stroke Association. Stroke 50(12):e344-e418. https:// doi.org/10.1161/STR.0000000000000211

Poznyak A, Grechko AV, Poggio P, Myasoedova VA, Alfieri V and Orekhov AN (2020) The diabetes mellitus-atherosclerosis connection: the role of lipid and glucose metabolism and chronic inflammation. Int J Mol Sci 21(5). https://doi.org/10.3390/ ijms 21051835

Prasad M, Khanna P, Katyal VK and Verma R (2020) Acute psychological stress is a trigger for stroke: a case-crossover study. Journal of stroke and cerebrovascular diseases : the official journal of National Stroke Association, 104799. https://doi. org/10.1016/j.jstrokecerebrovasdis.2020.104799

Prasad M, McBane R, Reriani M, Lerman LO, Lerman A (2016) Coronary endothelial dysfunction is associated with increased risk of venous thromboembolism. Thromb Res 139:17-21. https:// doi.org/10.1016/j.thromres.2015.12.024

Rafai MA, Fadel H, Gam I, Hakim K, El Moutawakkil B, Kissani N, Slassi I (2006) Reccurent stroke revealing catastrophic antiphospholipid syndrome with hepatitis $\mathrm{C}$ viral infection. Rev Neurol 162(11):1131-1134. https://doi.org/10.1016/s00353787(06)75128-1

Ramasamy R, Goldberg IJ (2010) Aldose reductase and cardiovascular diseases, creating human-like diabetic complications in an experimental model. Circ Res 106(9):1449-1458. https://doi. org/10.1161/CIRCRESAHA.109.213447

Ramos-Casals M, Cervera R, Lagrutta M, Medina F, García-Carrasco M, de la Red G, Bové A, Ingelmo M, Font J (2004) Clinical features related to antiphospholipid syndrome in patients with chronic viral infections (hepatitis $\mathrm{C}$ virus/HIV infection): description of 82 cases Clinical infectious diseases. an official publication of the Infectious Diseases Society of America 38(7):1009-1016. https://doi.org/10.1086/382537

Sangalli D, Polonia V, Colombo D, Mantero V, Filizzolo M, Scaccabarozzi C, Salmaggi A (2020) A single-centre experience of intravenous thrombolysis for stroke in COVID-19 patients Neurological sciences. official journal of the Italian Neurological Society and of the Italian Society of Clinical Neurophysiology 41(9):2325-2329. https://doi.org/10.1007/s10072-020-04591-3

Sato T, Sato S, Yamagami H, Komatsu T, Mizoguchi T, Yoshimoto T, Takagi M, Ihara M, Koga M, Iwata H, Matsushima M, Toyoda K and Iguchi Y (2020) D-dimer level and outcome of minor ischemic stroke with large vessel occlusion. J Neurol Sci 413. https://doi.org/10.1016/j.jns.2020.116814

Schlachetzki F, Theek C, Hubert ND, Kilic M, Haberl RL, Linker RA and Hubert GJ (2020) Low stroke incidence in the TEMPiS telestroke network during COVID-19 pandemic - effect of lockdown on thrombolysis and thrombectomy. J Telemed Telecare, 1357633X20943327. https://doi.org/10.1177/ 1357633X20943327

Schöberl F, Ringleb PA, Wakili R, Poli S, Wollenweber FA, Kellert L (2017) Juvenile Stroke Deutsches Arzteblatt international 114(31-32):527-534. https://doi.org/10.3238/arztebl.2017.0527

Song Z, Xu Y, Bao L, Zhang L, Yu P, Qu Y, Zhu H, Zhao W, Han Y and Qin C (2019) From SARS to MERS, thrusting coronaviruses into the spotlight. Viruses 11(1). https://doi.org/10.3390/v11010059

Soro-Paavonen A, Gordin D, Forsblom C, Rosengard-Barlund M, Waden J, Thorn L, Sandholm N, Thomas MC, Groop P-H (2012) Circulating ACE2 activity is increased in patients with type 1 diabetes and vascular complications. J Hypertens 30(2):375-383. https://doi.org/10.1097/HJH.0b013e32834f04b6

Spyropoulos AC, Ageno W and Barnathan ES (2020) Hospitalbased use of thromboprophylaxis in patients with COVID-19. Lancet (London, England). https://doi.org/10.1016/S01406736(20)30926-0

Stegbauer J, Thatcher SE, Yang G, Bottermann K, Rump LC, Daugherty A and Cassis LA (2019) Mas receptor deficiency augments angiotensin II-induced atherosclerosis and aortic aneurysm ruptures in hypercholesterolemic male mice. J Vasc Surg 70(5). https://doi.org/10.1016/j.jvs.2018.11.045

Stojanović SD, Fiedler J, Bauersachs J, Thum T, Sedding DG (2020) Senescence-induced inflammation: an important player and key therapeutic target in atherosclerosis. Eur Heart J. https://doi. org/10.1093/eurheartj/ehz919

Tiainen M, Meretoja A, Strbian D, Suvanto J, Curtze S, Lindsberg PJ, Soinne L, Tatlisumak T (2013) Body temperature, blood infection parameters, and outcome of thrombolysis-treated ischemic stroke patients. International journal of stroke : official journal of the International Stroke Society 8(8):632-638. https:// doi.org/10.1111/ijs.12039

Tunç A, Ünlübaş Y, Alemdar M, Akyüz E (2020) Coexistence of COVID-19 and acute ischemic stroke report of four cases. Journal of clinical neuroscience: official journal of the Neurosurgical Society of Australasia. https://doi.org/10.1016/j. jocn.2020.05.018

Turner AJ, Hiscox JA, Hooper NM (2004) ACE2: from vasopeptidase to SARS virus receptor. Trends Pharmacol Sci 25(6):291-294. https://doi.org/10.1016/j.tips.2004.04.001

Umapathi T, Kor AC, Venketasubramanian N, Lim CCT, Pang BC, Yeo TT, Lee CC, Lim PL, Ponnudurai K, Chuah KL, Tan PH, Tai DYH, Ang SPB (2004) Large artery ischaemic stroke in severe acute respiratory syndrome (SARS). J Neurol 251(10):12271231. https://doi.org/10.1007/s00415-004-0519-8

van Hinsbergh VWM (2012) Endothelium--role in regulation of coagulation and inflammation. Seminars in immunopathology 34(1). https://doi.org/10.1007/s00281-011-0285-5 
van Os GMA, Meijers JCM, Agar Ç, Seron MV, Marquart JA, Åkesson P, Urbanus RT, Derksen RHWM, Herwald H, MörgelinD E Groot PG, M (2011) Induction of anti- $\beta 2$-glycoprotein I autoantibodies in mice by protein $\mathrm{H}$ of Streptococcus pyogenes. J Thromb Haemost 9(12):2447-2456. https://doi.org/10.1111/ j.1538-7836.2011.04532.x

Velkoska E, Patel SK, Burrell LM (2016) Angiotensin converting enzyme 2 and diminazene: role in cardiovascular and blood pressure regulation. Curr Opin Nephrol Hypertens 25(5):384395. https://doi.org/10.1097/MNH.0000000000000254

Wallet SM, Puri V and Gibson FC (2018) Linkage of infection to adverse systemic complications: periodontal disease, toll-like receptors, and other pattern recognition systems. Vaccines 6(2). https://doi.org/10.3390/vaccines6020021

Wan Y, Shang J, Graham R, Baric RS and Li F (2020) Receptor recognition by the novel coronavirus from Wuhan: an analysis based on decadelong structural studies of SARS coronavirus. J Virol 94(7). https:// doi.org/10.1128/JVI.00127-20

Wang A, Mandigo GK, Yim PD, Meyers PM, Lavine SD (2020) Stroke and mechanical thrombectomy in patients with COVID-19: technical observations and patient characteristics. J Neurointerve Surg 12(7):648-653. https://doi.org/10.1136/neurintsurg-2020016220

Wang C, Horby PW, Hayden FG, Gao GF (2020) A novel coronavirus outbreak of global health concern. Lancet (London, England) 395(10223):470-473. https://doi.org/10.1016/S0140 6736(20)30185-9

Wang D, Hu B, Hu C, Zhu F, Liu X, Zhang J, Wang B, Xiang H, Cheng Z, Xiong Y, Zhao Y, Li Y, Wang X, Peng Z (2020) Clinical characteristics of 138 hospitalized patients with 2019 novel coronavirus-infected pneumonia in Wuhan. JAMA, China. https:// doi.org/10.1001/jama.2020.1585

Wang SY, Chen LK, Hsu SH, Wang SC (2012) Health care utilization and health outcomes: a population study of Taiwan. Health policy and planning 27(7):590-599. https://doi.org/10.1093/heapol/ czr080

Warren-Gash C, Blackburn R, Whitaker H, McMenamin J and Hayward $\mathrm{AC}$ (2018) Laboratory-confirmed respiratory infections as triggers for acute myocardial infarction and stroke: a self-controlled case series analysis of national linked datasets from Scotland. Euro Respir J 51(3). https://doi.org/10.1183/13993003.01794-2017

Watson AMD, Soro-Paavonen A, Sheehy K, Li J, Calkin AC, Koitka A, Rajan SN, Brasacchio D, Allen TJ, Cooper ME, Thomas MC, Jandeleit-Dahm KJA (2011) Delayed intervention with AGE inhibitors attenuates the progression of diabetes-accelerated atherosclerosis in diabetic apolipoprotein E knockout mice. Diabetologia 54(3):681-689. https://doi.org/10.1007/s00125010-2000-9

World Health Organization (2020) WHO coronavirus disease (COVID19) dashboard. [cited 21 December 2020];from: https://covid19. who.int

Wrapp D, Wang N, Corbett KS, Goldsmith JA, Hsieh C-L, Abiona O, Graham BS and McLellan JS (2020) Cryo-EM structure of the 2019-nCoV spike in the prefusion conformation. Science (New York, N.Y.) 367(6483), 1260-1263. https://doi.org/10.1126/science. abb2507

Wu Y, Xu X, Chen Z, Duan J, Hashimoto K, Yang L, Liu C, Yang C (2020) Nervous system involvement after infection with COVID19 and other coronaviruses. Brain Behav Immun. https://doi. org/10.1016/j.bbi.2020.03.031

Xiang YT, Yang Y, Li W, Zhang L, Zhang Q, Cheung T, Ng CH (2020) Timely mental health care for the 2019 novel coronavirus outbreak is urgently needed. The lancet Psychiatry 7(3):228-229. https://doi.org/10.1016/S2215-0366(20)30046-8

Xie X, Xudong X, Chen J, Junzhu C, Wang X, Xingxiang W, Zhang F, Furong Z, Liu Y, Yanrong L (2006) Age- and gender-related difference of ACE2 expression in rat lung. Life Sci 78(19):21662171. https://doi.org/10.1016/j.lfs.2005.09.038

Xu Z, Shi L, Wang Y, Zhang J, Huang L, Zhang C, Liu S, Zhao P, Liu H, Zhu L, Tai Y, Bai C, Gao T, Song J, Xia P, Dong J, Zhao J, Wang F-S (2020) Pathological findings of COVID-19 associated with acute respiratory distress syndrome. Lancet Respir Med 8(4):420-422. https://doi.org/10.1016/S2213-2600(20)30076-X

Yang B, Wang T, Chen J, Chen Y, Wang Y, Gao P, Li G, Chen F, Li L, Wang Z, Zhang H, Song H, Ma Q, Jiao L (2020) Impact of the COVID-19 pandemic on the process and outcome of thrombectomy for acute ischemic stroke. J Neurointerv Surg 12(7):664-668. https://doi.org/10.1136/neurintsurg-2020-016177

Yao XH, Li TY, He ZC, Ping YF, Liu HW, Yu SC, Mou HM, Wang LH, Zhang HR, Fu WJ, Luo T, Liu F, Chen C, Xiao HL, Guo HT, Lin S, Xiang DF, Shi Y, Li QR, Huang X, Cui Y, Li XZ, Tang W, Pan PF, Huang XQ, Ding YQ and Bian XW (2020) [A pathological report of three COVID-19 cases by minimally invasive autopsies]. Zhonghua bing li xue za zhi $=$ Chinese journal of pathology 49(0), E009. https://doi.org/10.3760/ cma.j.cn112151-20200312-00193

Yende S, D’Angelo G, Kellum JA, Weissfeld L, Fine J, Welch RD, Kong L, Carter M, Angus DC (2008) Inflammatory markers at hospital discharge predict subsequent mortality after pneumonia and sepsis. Am J Respir Crit Care Med 177(11):1242-1247. https://doi.org/10.1164/rccm.200712-1777OC

Yost CC, Schwertz H, Cody MJ, Wallace JA, Campbell RA, Vieirade-Abreu A, Araujo CV, Schubert S, Harris ES, Rowley JW, Rondina MT, Fulcher JM, Koening CL, Weyrich AS, Zimmerman GA (2016) Neonatal NET-inhibitory factor and related peptides inhibit neutrophil extracellular trap formation. J Clin Investig 126(10):3783-3798. https://doi.org/10.1172/ JCI83873

Yuan T, Yang T, Chen H, Fu D, Hu Y, Wang J, Yuan Q, Yu H, Xu W, Xie X (2019) New insights into oxidative stress and inflammation during diabetes mellitus-accelerated atherosclerosis. Redox Biol 20:247-260. https://doi.org/10.1016/j.redox.2018.09.025

Zhang P, Zhu L, Cai J, Lei F, Qin J-J, Xie J, Liu Y-M, Zhao Y-C, Huang X, Lin L, Xia M, Chen M-M, Cheng X, Zhang X, Guo D, Peng Y, Ji Y-X, Chen J, She Z-G, Wang Y, Xu Q, Tan R, Wang H, Lin J, Luo P, Fu S, Cai H, Ye P, Xiao B, Mao W, Liu L, Yan Y, Liu M, Chen M, Zhang X-J, Wang X, Touyz RM, Xia J, Zhang B-H, Huang X, Yuan Y, Rohit L, Liu PP, Li H (2020) Association of inpatient use of angiotensin converting enzyme inhibitors and angiotensin II receptor blockers with mortality among patients with hypertension hospitalized with COVID-19. Circ Res. https:// doi.org/10.1161/CIRCRESAHA.120.317134

Zhang W, Zhao Y, Zhang F, Wang Q, Li T, Liu Z, Wang J, Qin Y, Zhang X, Yan X, Zeng X and Zhang S (2020) The use of antiinflammatory drugs in the treatment of people with severe coronavirus disease 2019 (COVID-19): the perspectives of clinical immunologists from China. Clini Immunol (Orlando, Fla.) 214, 108393. https://doi.org/10.1016/j.clim.2020.108393

Zhang Y, Xiao M, Zhang S, Xia P, Cao W, Jiang W, Chen H, Ding X, Zhao H, Zhang H, Wang C, Zhao J, Sun X, Tian R, Wu W, Wu D, Ma J, Chen Y, Zhang D, Xie J, Yan X, Zhou X, Liu Z, Wang J, Du B, Qin Y, Gao P, Qin X, Xu Y, Zhang W, Li T, Zhang F, Zhao Y, Li Y, Zhang S (2020) Coagulopathy and antiphospholipid antibodies in patients with Covid-19. N Eng Med 382(17):e38. https://doi. org/10.1056/NEJMc2007575

Zhou P, Yang XL, Wang XG, Hu B, Zhang L, Zhang W, Si HR, Zhu Y, Li B, Huang CL, Chen H-D, Chen J, Luo Y, Guo H, Jiang RD, Liu MQ, Chen Y, Shen XR, Wang X, Zheng XS, Zhao K, Chen QJ, Deng F, Liu LL, Yan B, Zhan FX, Wang YY, Xiao GF, Shi ZL (2020) A pneumonia outbreak associated with a new coronavirus of probable bat origin. Nature 579(7798):270-273. https:// doi.org/10.1038/s41586-020-2012-7 
Zuniga MC, Raghuraman G, Hitchner E, Weyand C, Robinson W, Zhou W (2017) PKC-epsilon and TLR4 synergistically regulate resistin-mediated inflammation in human macrophages. Atherosclerosis 259:51-59. https://doi.org/10.1016/j. atherosclerosis.2017.02.021

Zuo Y, Yalavarthi S, Shi H, Gockman K, Zuo M, Madison JA, Blair C, Weber A, Barnes BJ, Egeblad M, Woods RJ, Kanthi Y and
Knight JS (2020) Neutrophil extracellular traps in COVID-19. JCI Insight 5(11). https://doi.org/10.1172/jci.insight.138999

Publisher's Note Springer Nature remains neutral with regard to jurisdictional claims in published maps and institutional affiliations. 